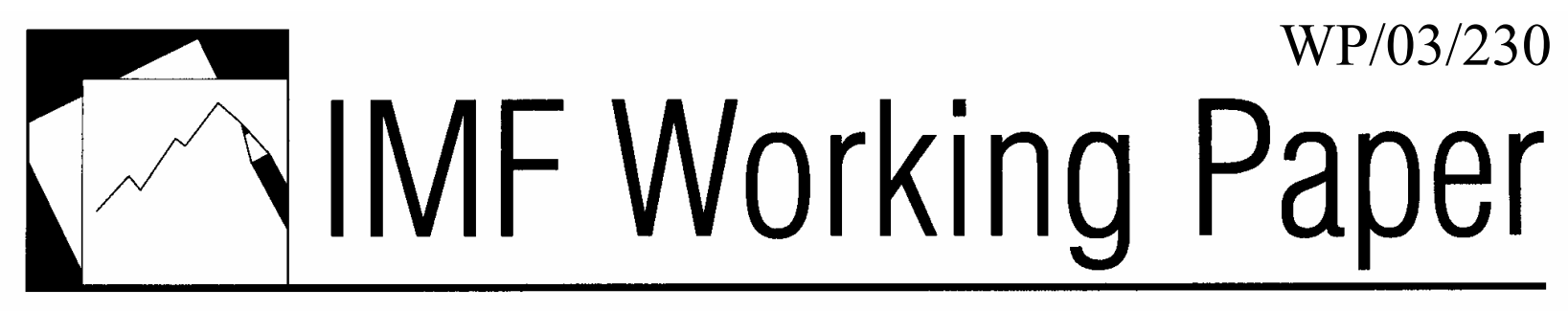

\title{
Output Response to Currency Crises
}

\author{
Poonam Gupta, Deepak Mishra, and \\ Ratna Sahay
}




\title{
IMF Working Paper
}

\author{
Research Department
}

\section{Output Response to Currency Crises}

\author{
Prepared by Poonam Gupta, Deepak Mishra, and Ratna Sahay ${ }^{1}$
}

November 2003

\begin{abstract}
The views expressed in this Working Paper are those of the author(s) and do not necessarily represent those of the IMF or IMF policy. Working Papers describe research in progress by the author(s) and are published to elicit comments and to further debate.
\end{abstract}

This paper analyzes the behavior of output during currency crises using a sample of 195 crisis episodes in 91 developing countries during 1970-98. It finds that more than two-fifths of the crises in the sample were expansionary, and that output contraction was greater in large and more developed economies than in small and less developed economies. Currency crises have not been any more contractionary in the 1990s than in the previous two decades. Countries that traded less with the rest of the world, that had a relatively open capital account, and where crises were preceded by large capital inflows were more likely to be associated with contraction during crises. The contraction was more pronounced if trade competitors devalued, oil prices rose during the crisis, and postcrisis period was marked by tight monetary policy and expansionary fiscal policy.

JEL Classification Numbers: F32, F41, F43

Keywords: Currency crises, emerging markets, output growth

Authors’ E-Mail Addresses: pgupta@imf.org; rsahay@imf.org; dmishra@worldbank.org

\footnotetext{
${ }^{1}$ Poonam Gupta and Ratna Sahay are with the IMF and Deepak Mishra is with the World Bank. The views expressed in this paper are those of the authors and not necessarily of the organizations with which they are affiliated. They would like to thank Michael Adler, Michael Bordo, Eduardo Borensztein, Enrica Detragiache, Stanley Fischer, Homi Kharas, Amartya Lahiri, Timothy Lane, Prakash Loungani, Paolo Mauro, Gian Maria Milesi-Ferretti, Christian Mulder, Carmen Reinhart, Nouriel Roubini, Sergio Rebelo, Andrew Rose, Xavier Salai-Martin, Carlos Vegh, and Jeromin Zettelmeyer, as well as seminar participants at UC Santa Cruz, LACEA, a joint IMF/ World Bank workshop, and the second Annual IMF Research Conference for many insightful comments. Haiyan Shi provided excellent research assistance.
} 
I. Introduction 3

II. Data and (the Not-So-Trivial) Measurement Issues..................................................... 4

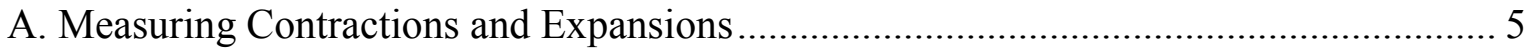

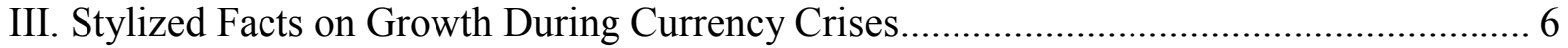

A. Contractions and Expansions During Crises....................................................... 6

B. Severity of Output Crises Over Time.................................................................. 6

C. Severity of Output Crises Across Countries ....................................................... 7

IV. What Explains the Behavior of Output During Crises? .......................................... 8

A. Liability Dollarization and External Debt Burden .................................................. 8

B. Sudden Stop or Reversal of External Capital Inflows............................................. 9

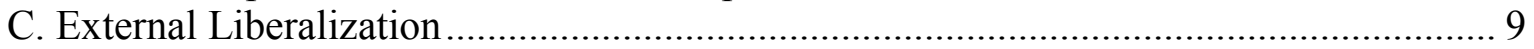

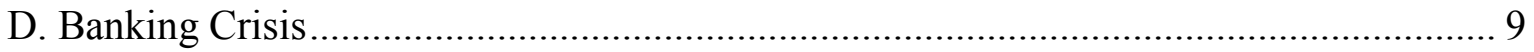

E. Short-Term Debt and Liquidity Crisis.......................................................... 9

F. Devaluation and External Trade ...................................................................... 10

G. Monetary and Fiscal Policies ........................................................................... 10

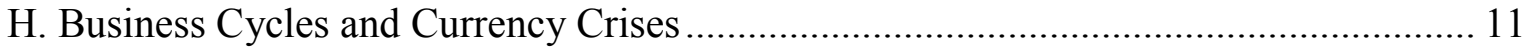

V. Econometric Analysis and Results....................................................................... 11

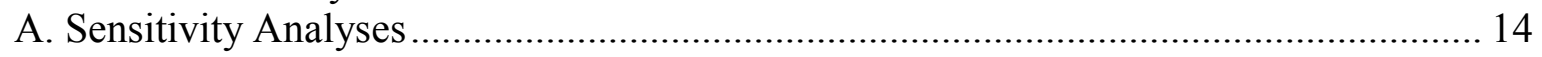

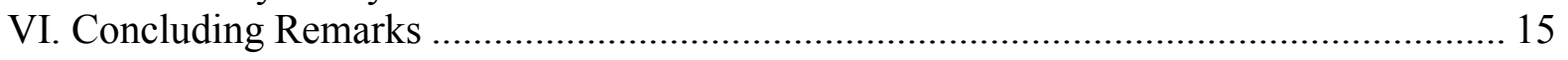

Tables

1. Changes in Growth Rate: Correlation Coefficient Between Different Measures .............. 17

2. Currency Crises and Output Behavior: Stylized Facts ............................................... 18

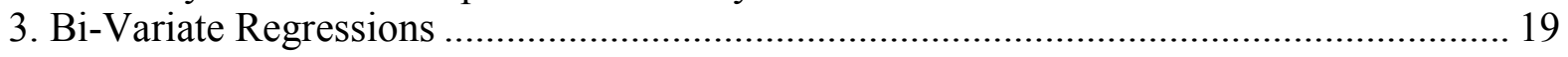

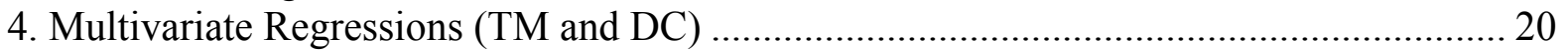

5. Multivariate Regressions (TM, DC, and GC) ......................................................... 21

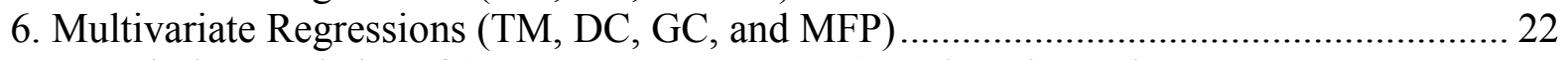

7. Descriptive Statistics of (gpost_2 - gpre_3, tranq) Under Alternative

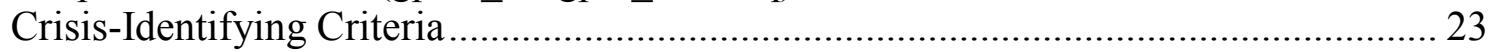

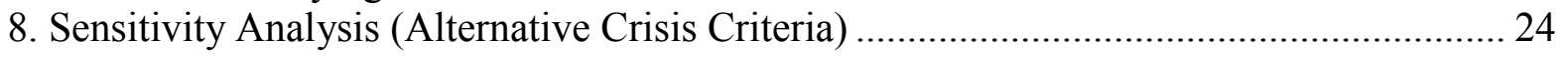

9. Sensitivity Analysis (Identified Stylized Facts) ....................................................... 25

Figures

1. Magnitude of Contraction/Expansion During Selected Currency Crises ......................... 26

2. Frequency Distribution of Average Growth Rate During the Crisis and One

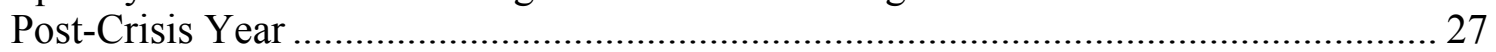

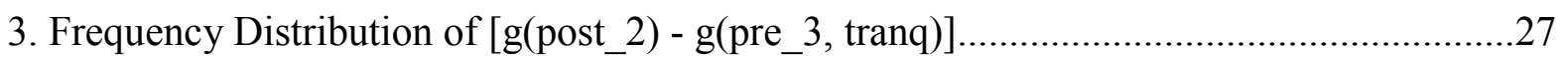

4. Frequency Distribution of [g(post_2) - g(pre_3, tranq)] Under Alternative

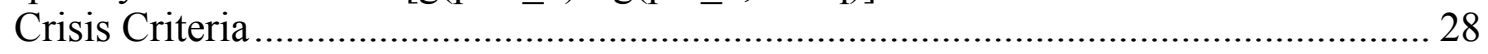

5. Severity of Crises: A Comparison Across Three Decades ........................................... 29

6. Contribution of Various Factors to Output Response to Currency Crisis ........................ 30

Appendixes

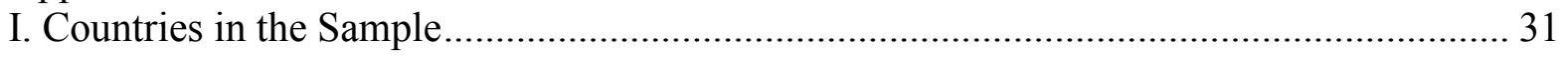

II. The Crisis Episodes ................................................................................................. 32

III. Data Sources and Construction of Variables .......................................................... 33

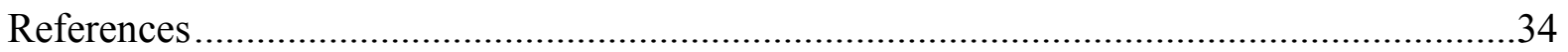




\section{INTRODUCTION}

The East Asian currency crises in 1997/98 focused the world's attention on the economy-wide damage such crises can inflict. The Indonesian and Thai economies, for example, contracted by 13 and 10 percent, respectively, during the crisis. ${ }^{2}$ Since then, policymakers around the world have been increasingly preoccupied with crisis prevention and management, with the latter focused on minimizing output losses during crises. More recently, the output decline during the Argentina crisis (2002) was nearly 11 percent.

However, currency crises have not always been contractionary-for example, the crises in Brazil (1979), Colombia (1985), China (1994), Venezuela (1984 and 1987), and Hungary (1993), were associated with higher output growth, as compared with the precrisis period (Figure 1). Why is the output performance so varied, not just in magnitude but even in the direction it might take?

There are several ways in which a currency crisis may affect output. The earlier literature - through the 1980s - emphasized the beneficial effects arising from the large depreciation of the domestic currency that characterizes such crises. A depreciation, by correcting an overvalued currency or by making the exchange rate more competitive, was expected to spur growth by expanding the tradable goods sector. ${ }^{3}$ The more recent literature focuses on the negative effects: a sudden stop or reversal of capital inflows during a crisis can slow down growth; a rise in the external debt burden from devaluation in the presence of liability dollarization can lower investment activity and growth. The slowdown may be worse if the currency crisis is accompanied by a banking crisis, or by a competitive devaluation by other countries. Moreover, the stance of fiscal and monetary policies pursued during crises, and the prevailing global economic environment are also likely to have a bearing on growth.

Using a broad sample of 195 currency crises in 91 countries from 1970 to 1998, this paper establishes some stylized facts on the behavior of output growth before and after crises. The paper finds that, while the majority of crises have been contractionary, more than 40 percent were expansionary. While growth accelerated in more than half of the crises in small emerging market countries, the corresponding number for large emerging markets was somewhat smaller, but still substantial, at 30 percent. To our knowledge, this is the first study on output response to currency crises that attempts to include as large a sample of crisis episodes as is available for both emerging markets and low-income countries.

On the question of whether the severity of output crises changed over time, our expectation was that with increasing financial globalization, the advent of sharp capital flow reversals, and adverse balance sheet effects of sudden devaluations, the positive effects of a

\footnotetext{
${ }^{2}$ Contraction (expansion) is defined as the difference between the growth rate during the crisis years and the average growth rate in precrisis tranquil years (See Section III).

${ }^{3}$ See Connolly (1983), Taylor and Rosensweig (1990), Edwards (1986), Morley (1992) and Kamin and Klau (1998).
} 
devaluation on the tradable goods sector would be insignificant, at least in the short run. We were, therefore, surprised to find that the ratio of expansionary to contractionary crises did not change much in the last three decades - both for large as well as for small emerging markets.

This paper also attempts to isolate the factors or country characteristics that are associated with expansionary or contractionary crises. Regression analyses show that growth slowdown is more pronounced when: the bigger the surge in private capital flows prior to the crisis, the more open the capital and current accounts, the larger the precrisis business cycle boom, and the higher the per capita income of the country. Factors that contribute positively to growth are mostly related to international trade. The expansion is stronger when the bigger the share of external trade in economic activity and the stronger the growth of exports in response to devaluation. Among the external factors, competitive devaluation (measured in terms of third-country real devaluation), and a rise in crude oil prices have a negative and significant impact on growth. Tight monetary policy and expansionary fiscal policy are associated with adverse growth outcomes. However, the change in the level of fiscal deficit between crisis and postcrisis years does not seem to have any bearing on growth.

The findings are robust to several sensitivity tests that identify currency crises in different ways and use alternative methods of measuring the impact on growth during a crisis. We also control for the size of the external shock itself, by using the change in international reserves and nominal depreciation between the crisis and precrisis years as a proxy for the nominal severity of the crisis. The results hold even when the exercise is conducted using different definitions to identify currency crisis dates.

One question that this paper is unable to address fully is the policy response to crises, which is likely to be endogenous to growth outcomes. Given the typical fast-pace evolution of crises, high frequency data would be needed to address the endogeneity issue. Unfortunately, output data for most developing countries are available at annual frequency only. Since our primary goal was to establish patterns of output behavior using as large a sample of countries as possible, the issue of macroeconomic policy response under currency crises could not be addressed satisfactorily in this paper.

The rest of the paper is organized as follows. Section II explains the methodology used to identify currency crisis dates and discusses various ways of measuring output contraction or expansion. Section III presents the stylized facts on output growth during currency crises. Section IV identifies potential factors that are likely to influence output growth during currency crises, and Section V presents the regression results. Section VI concludes.

\section{Data And (The Not-So-Trivial) Measurement IsSues}

We started with a sample of 108 developing countries during 1970-98, drawn from four studies on currency crises: Berg and Pattillo (1999), Frankel and Rose (1996), Goldstein, Kaminsky, and Reinhart (2000), and Milesi-Ferretti and Razin (1998), referred to as BP, FR, GKR, and MR, respectively, in this paper. (For a list of countries, see Appendix I.) These 
studies use somewhat different methodologies to identify currency crises (Appendix II). For the purposes of our analysis, we use a simple majority rule to identify the crises dates in the 108 countries. Specifically, for a given country, we select a particular year as the crisis year only if the majority of these papers identify it as a crisis year. Using this criterion, we dropped 11 countries from our sample as crises in those countries failed to pass the majority test. $^{4}$ The remaining sample of 97 countries had a total of 229 crises. We further dropped 34 crisis episodes and 6 countries because data on key variables around the time of the crisis were not available. ${ }^{5}$ Thus, we conduct our analysis on 195 crisis episodes in 91 countries (42 African countries, 17 Asian countries, 20 Latin American countries, and 12 countries from Central and Eastern Europe and Middle East), of which, 24 crises occurred in the 1970 s, 83 in the 1980s, and 88 in the 1990s. ${ }^{6}$ To check for the robustness of our results, where appropriate, we also report four sets of results based on crises identified in the four studies.

Data used in this paper were obtained from the IMF's International Financial Statistics, and World Economic Outlook, the World Bank's World Development Indicators and Global Development Finance, the Economist Intelligence Unit, and JP Morgan's website. Details on the sources and construction of variables are provided in Appendix III.

\section{A. Measuring Contractions and Expansions}

To measure the effect of a currency crisis on growth, we define ( $\left.g_{\text {post }} n-g_{\text {pre }} m\right)$ as the difference in the average growth rate between $m$ precrisis years and $n$ postcrisis years, where $\mathrm{g}$ is the growth rate of real GDP. ${ }^{7}$ If $\left(g_{\text {post }} \mathrm{n}-\mathrm{g}_{\text {pre_e }} \mathrm{m}\right)$ is positive, we call it an expansionary episode and if it is negative, it is termed a contractionary episode. We also define ( $\mathrm{g}_{\text {post }} \mathrm{n}^{-}$ $\mathrm{g}_{\text {pre_ } \mathrm{m} \text {, tranq }}$ ) as the difference in the average growth rate between the nearest $\mathrm{m}$ "tranquil" precrisis years and n postcrisis years, where "tranquil" years exclude any crisis years. We then experimented with several different values for $\mathrm{m}$ and $\mathrm{n}$ and found that these measures were highly correlated (Table 1$)$. Of the measures listed in Table 1, we found ( $\mathrm{g}_{\text {post } 22-}$ g pre_3,tranq) to be the most intuitively appealing. An average of the three precrisis years

\footnotetext{
${ }^{4}$ Countries excluded from our sample are Barbados, Belize, Djibouti, Grenada, Haiti, Oman, Panama, Seychelles, St. Vincent and Grenadines, Tunisia, and Servia and Montenegro (formerly Yugoslavia).

${ }^{5}$ These countries are Guinea, Israel, Liberia, Samoa, Taiwan Province of China, and Vanuatu.

${ }^{6}$ Some of these studies do not cover the period until 1998. Therefore, where possible, we update the crises dates until 1998 by using the respective methodologies of the authors.

${ }^{7}$ While we experimented with measures that capture the deviation of growth rate from a linear or nonlinear trend (such as the HP filter), we do not report the results as these measures seem inappropriate for analyzing the short-run effects of currency crises, in general, or for many developing countries undergoing structural changes frequently.
} 
smoothes out large fluctuations that may occur in a particular year (due to, say, a bumper harvest or a natural calamity). Similarly, an average of two postcrisis years, rather than simply using the first postcrisis year, would take care of the measurement problem that might arise if a crisis occurred very early or late in a given year. ${ }^{8}$ In any event, we conducted sensitivity analyses using other measures and found the results to be robust to alternative definitions of growth slowdown.

Other studies that look at the short-run growth effects of crises have used measures similar to ours (for example, see Bordo and Eichengreen, 2001). Studies examining longer run effects of crises have also used similar precrisis windows, but longer postcrisis windows (Aziz, Caramazza, and Salgado, 2000).

\section{Stylized Facts on Growth During Currency Crises}

\section{A. Contractions and Expansions During Crises}

We begin by looking at the frequency distribution of the postcrisis growth rate of output, $g_{\text {post }} 2$, in Figure 2. It shows that there is a wide variation in postcrisis growth rates, and the distribution approximates a normal distribution. ${ }^{9}$ Only 28 percent of the crises are associated with a decline in growth rate and only in 3 percent of the episodes - Nicaragua in 1979 and Uruguay in 1982 — does the growth rate decline by more than 10 percent.

The frequency distribution of $\mathrm{g}_{\text {post_2 }}-\mathrm{g}_{\text {pre_3,tranq }}$, though more skewed toward a contraction, also shows a large variation in the postcrisis growth rates. Figure 3 shows that 43 percent of the crises are expansionary and 57 percent of the crises are contractionary in the sample. Average expansion during the expansionary episodes is 3.5 percent, and average contraction during the contractionary episodes is 4.8 percent. Only 6 percent of the crises in the sample experienced a contraction exceeding 10 percent. This pattern is robust to alternative ways of identifying crises (Figure 4) for the 14 countries that were common across the studies.

\section{B. Severity of Output Crises Over Time}

The pattern of growth rates has been quite similar in the 1970s, 1980s and 1990s (Figure 5, first panel). The growth rate significantly slows down between the precrisis and crisis year-by 3 percentage points in the 1970s, 2.5 percentage points in the $1980 \mathrm{~s}$, and nearly 2 percentage points in the 1990s. The crisis year is generally the trough of the growth curve, with the growth rate picking up the year after the crisis and reverting to the precrisis

\footnotetext{
${ }^{8}$ For example, the real effects of the Mexican crisis of December 1994 would not be captured, if $n=1$.

${ }^{9}$ The Jarque-Bera test statistic indicates that the null hypothesis of a normal distribution cannot be rejected.
} 
level by the second year after the crisis. A graph of the frequency distribution of ( $\mathrm{g}_{\text {post }} 2_{-}$ g pre_3,tranq) also seems similar across different decades (Figure 5, second panel), although the number of expansions and contractions vary by decades. Given that the recent literature has focused more on the contractionary aspects of the crises in the $1990 \mathrm{~s}$, it is surprising to see that 42 percent of the crises were expansionary in the 1990s as compare with 28 percent in the 1970 s and 50 percent in the 1980s.

To confirm the pattern described above, we regress ( $\left.g_{\text {post } 22}-g_{\text {pre } 3 \text {,tranq }}\right)$ on dummies for each of the three decades in a simple OLS framework (with heteroskedastically consistent standard errors). Coefficients of the dummies measure the average contraction/expansion during crises in the respective decades. As indicated in Table 2, on average, crises have been contractionary in all three decades. It was somewhat of a surprise to see that the magnitude of contraction has steadily fallen, from -3.0 in the 1970 s to -1.1 in the 1980 s to -0.8 in the 1990s. However, the null hypothesis that the coefficients are identical across the three decades is rejected at the 10 percent significance level for only the 1970s compared with the 1990s. Finally, if we limit the sample to only those crises that were associated with a contraction, the average contraction was not significantly more severe during the 1990s than in the 1970s or the 1980s. Thus, there does not appear to be any evidence to support the popular view that the severity of crises has systematically worsened in the 1990s.

We further compare the output response during crisis episodes during which a large number of countries were simultaneously affected — namely, the East Asian crisis in 1997, the debt crisis in Latin America (LA) in the 1980s, and the Mexican crisis in $1994 .{ }^{10}$ Interestingly, we find that, though the coefficient of the East Asian crisis is the largest, the average contraction during the East Asian crisis is not significantly different from that during either the LA debt crisis or the Mexican crisis (Table 2).

\section{Severity of Output Crises Across Countries}

A significant number of large expansions in the sample occurred in low-income, small open economies, several of them in Africa-some examples are Central African Republic in 1994, Chad in 1981, Ethiopia in1993, Gabon in1981, Ghana in1978, Republic of Congo in 1994, and Senegal in 1981. We categorized countries by the volume of foreign capital they received during the sample period. To see whether a pattern could be established among countries that were exposed to varying levels of foreign capital, we defined large emerging markets (LEMs) as countries that received, on average, US\$100 million or more of private external capital flows per year between 1970-98, and small emerging markets (SEMs) as those countries that received less than US\$100 million (Appendix I). Indeed, only 30 percent of crises in LEMs, are associated with an expansion as compared with about 50 percent in the SEMs.

${ }^{10}$ The LA debt crisis episodes include 1982-83 in the following countries: Argentina, Bolivia, Brazil, Chile, Ecuador, Mexico, and Uruguay. The Mexican crisis event includes Argentina and Mexico in 1994/95. The East Asian crisis includes crises in Indonesia, Korea, Malaysia, Philippines, and Thailand in 1997. 
Formally, we regressed ( $g_{\text {post } 2}-g_{\text {pre } 3 \text {,tranq }}$ ) on dummies for LEMs and SEMs. The estimated coefficient for the LEMs dummy variable was -3.07 , while that for the SEMs dummy was 0.24 and the two coefficients were statistically significantly different from each other. In other words, while crises in LEMs have, on average, been contractionary, crises in SEMs were expansionary but insignificant. Finally, by limiting the sample to only LEMs, we confirm our earlier finding for the whole sample - the average growth contraction during crises within LEMs did not change significantly across the three decades (Table 2). These results remain unchanged qualitatively if we redefine LEMs and SEMs on the basis of the size of the economy (GDP in US\$).

In summary, while the majority of currency crises in the sample have been contractionary, a large proportion, more than 40 percent, has been expansionary. Second, there is no significant difference in the ratio of expansionary to contractionary crises in the last three decades. Contrary to the common view, the crises during the 1990s were not more contractionary, on average, than the previous two decades. Third, the magnitude of contraction in contractionary crises and expansion in expansionary crises has also not changed significantly in the last three decades. Finally, consistent with popular perception, large emerging markets experienced more contractionary crises than small emerging markets.

\section{What Explains the Behavior of OUtPut During Crises?}

How output responds to a currency crisis is likely to depend on a multitude of factors - the conditions prevailing in the real, external, and financial sectors at the time of the crisis, fiscal and monetary policies implemented during the crisis, and the structural characteristics of the economy. Our empirical analysis relies heavily on the explanations provided in the crisis literature, outlined below, that points to several channels of influence.

\section{A. Liability Dollarization and External Debt Burden}

When the liabilities of domestic firms are denominated in foreign currency, a devaluation raises their debt burden. As a consequence, firms find it difficult to service existing debt or raise new loans, which, in the aggregate, is reflected in a decline in investment and economic activity. ${ }^{11}$ Since it is not unusual for developing countries to borrow externally, they are particularly vulnerable to this effect. We attempt to capture this effect in our empirical work by including the change in external long-term debt burden as one of the explanatory variables. This variable is measured in two ways - in nominal terms (NOMINAL $\triangle$ DEBT) and in real terms (REAL $\triangle$ DEBT).

${ }^{11}$ See Bruno (1979), van Wijnbergen (1986), Calvo (1998), and Mishkin (1999). 


\section{B. Sudden Stop or Reversal of External Capital Inflows}

Calvo and Reinhart (1999) show that, if a currency crisis is accompanied by a sudden stop or reversal of external capital inflows, and the associated loans to domestic projects is of shorter maturity than the projects themselves, it increases the incidence of nonperforming loans and reduces productive activity. Thus, countries that have been recipients of large capital inflows are more likely to experience a contraction following a currency crisis. Accordingly, we include the three-year cumulative flow of external private capital prior to the year of the crisis (CAPFLOW) expressed in percent of GDP as one of the explanatory variables.

\section{External Liberalization}

Open capital accounts undermine the authorities' ability to prevent capital from flowing out or to undertake countercyclical policies during currency crises. The severity of the crisis is worse if the capital account was opened without adequately strengthening domestic regulations and supervision of financial institutions. To adequately capture this effect, we include a variable that proxies controls on foreign exchange and capital account transactions (CAPCON), which is used as an interaction term with the private capital flows variable in our analysis. ${ }^{12}$ We want to see whether output crises were more severe in countries with more open capital accounts and experiencing capital flow reversals.

\section{Banking Crisis}

It is not uncommon for the banking sector to come under stress at the time of the currency crisis. With devaluation adversely affecting the balance sheets of their clients and increasing their nonperforming loans, banks may roll back their lending activities, giving rise to a "credit crunch" (Mishkin, 1999). Accordingly, we include a banking crisis dummy (BANK) to see whether its simultaneous occurrence worsened output performance.

\section{E. Short-Term Debt and Liquidity Crisis}

Rodrik and Velasco (1999) show that difficulties in rolling over short-term debt during currency crises could squeeze liquidity in the economy, and shrink the level of economic activity. They find the ratio of short-term external debt to foreign exchange reserves (DEBT_RESERVES) to be a robust predictor of financial crises and their severity. ${ }^{13}$ To see whether output is also affectedly adversely, we include DEBT_RESERVES in our regressions.

\footnotetext{
${ }^{12}$ Capital account restrictions refer to the lack of convertibility of the domestic currency for capital account transactions. Exchange rate restrictions refer to the regulation of nominal exchange rate or when the country maintains dual or triple exchange rates.

${ }^{13}$ Rodrik and Velasco (1999) define a currency crisis as a significant reversal of external capital flows.
} 


\section{F. Devaluation and External Trade}

A devaluation of the currency could restore competitiveness of the economy and provide a boost to the production of tradables (provided the Marshall-Lerner condition holds). However, competitiveness increases only if nominal devaluation translates into a real devaluation of the exchange rate, there is no concurrent devaluation by other competitive countries, and the effect of devaluation is not offset by a negative terms-of-trade shock. Additionally, the trade regime needs to be sufficiently open to realize the beneficial effects of the devaluation. ${ }^{14}$

To test whether devaluation affects output positively via the growth of exports, we use measures of overvaluation of the exchange rate (against the U.S. dollar, OVERVAL_US, and against major trading partners, OVERVAL_MULTI), average export growth rate (X_GROWTH) during the crisis year and the first postcrisis year, share of trade (exports plus imports) in GDP (OPEN), and a measure of competitive devaluation by other countries (COMP_DEVAL) in the regressions.

\section{G. Monetary and Fiscal Policies}

Monetary policy is often tightened to stem the extent of speculative attack on the currency and to prevent foreign exchange reserves from falling rapidly. Similarly, fiscal policy may be tightened during a crisis to signal a strong policy resolve on the part of the authorities and to compensate for the fiscal burden that inevitably arises following a crisis. While a strong case in favor of tight macroeconomic policies can reasonably be made to stem the slide of the domestic currency or prevent capital outflows, their effect on output growth is not obvious.

To proxy for monetary and fiscal policies we use percentage change in broad real money supply during the crisis $(\Delta \mathrm{M} 2)$; change in the real interest rate between the crisis year and the precrisis year (REAL $\triangle \mathrm{INT})$; the postcrisis level of the fiscal deficit as a percentage of GDP (FISCAL_DEF); and change in fiscal deficit ( $\triangle$ FISCAL_DEF) between the precrisis and crisis year. $^{15}$

14 The literature also offers several other demand and supply effects such as real balance effect, redistribution effect, costly input effect, and others, through which a currency devaluation can affect growth, see Agenor (1991) and Lizondo and Montiel (1989). We do not include these variables because either it was not possible to measure such effects or the required data were unavailable.

${ }^{15}$ As mentioned earlier, the endogeneity issue could not be dealt with precisely in this analysis, given our inability to use data of higher than annual frequency. 


\section{H. Business Cycles and Currency Crises}

Milesi-Ferretti and Razin (1998) show that crises that occur during booms are usually contractionary, and those occurring during troughs are expansionary. To allow for the possibility that countries could be at different stages in the business cycle when the crisis occurred, we include a dummy for precrisis business cycle conditions (BCDUM). ${ }^{16}$

We include a number of control variables for domestic and global economic conditions at the time of the crisis to facilitate unbiased estimation across crisis episodes. The domestic variables are loss in foreign exchange reserves (RESERVE_LOSS), to allow for the size of the country-specific external shock; per capita income (PCY), to proxy for the level of development of the economy; and size of the economy in terms of U.S. dollars (GDP\$), to see whether larger countries with more diversified economic base experience less disruption than smaller economies.

The global economic variables are U.S. real interest rate (USINT), growth rate in industrial countries (GRIND) or growth rate in G-7 countries (GRG7), change in crude oil price $(\Delta \mathrm{OIL})$, and change in the terms of trade $(\Delta \mathrm{TOT})$.

\section{ECONOMETRIC ANALYSIS AND RESUlts}

We estimate the following cross-section regression equation:

$$
\left(\mathrm{g}_{\text {post_2 }}-\mathrm{g}_{\text {pre_3,tranq }}\right)_{\mathrm{i}}=\alpha+\sum_{\mathrm{k}} \beta_{\mathrm{k}} \mathrm{X}_{\mathrm{ki}}+\varepsilon_{\mathrm{i}}, \quad \varepsilon_{\mathrm{i}} \approx \mathrm{N}\left(0, \sigma_{\mathrm{i}}{ }^{2}\right), \mathrm{i}=1,2, \ldots \ldots . ., \mathrm{I}
$$

where $\mathrm{X}_{\mathrm{k}}$ is $\mathrm{k}^{\text {th }}$ explanatory variable, $\mathrm{i}$ denotes the $\mathrm{i}^{\text {th }}$ crisis episode, and $\mathrm{I}$ is the total number of crisis episodes (ranging from 141 to 195 ), $\varepsilon_{\mathrm{i}}$ is the error term which is distributed normally with mean 0 and variance $\sigma_{i}^{2}$. Lagged values of the domestic variables were used to avoid potential endogeneity problems, while contemporaneous values of global factors were used to control for prevailing global economic conditions.

While the core set of regressions were run on 157 crisis episodes, robustness checks are consistently performed by dropping extreme observations from the sample. Typical examples were cases of extreme devaluation where changes in nominal debt burden and short term debt variables exhibited very large fluctuations. Results are also reported for samples that exclude observations on nominal external debt burden greater than 5000 percent

\footnotetext{
${ }^{16}$ The dummy takes a value of -1 if in three precrisis years the average growth rate is less than 0 percent, value 0 if the growth rate is $0-3$ percent, and value 1 if the growth rate exceeds 3 percent.
} 
(4 episodes) and when the ratio of short-term external debt to foreign exchange reserves exceeded 30 (11 episodes). ${ }^{17}$

The multivariate regression results are reported in Tables 4-6. Regressions reported in Table 4 include only domestic nonpolicy variables. In Table 5, global variables are added. Finally, we add the policy variables in Table 6. In Tables 4 and 5, the first column reports the results for the entire sample of 157 crises, for which the data are available; in the second column, extreme observations of change in long-term external debt burden are excluded, and in the last column, extreme observations of short-term debt to reserve ratio are also excluded. For brevity, Table 6 only reports regression results for the sample excluding extreme observations. Instead, additional results are reported for different instruments of monetary and fiscal policies.

The regression results are broadly similar across different specifications. In all specifications, the precrisis volume of capital flows, capital account restrictions, precrisis business cycle condition, and per capita income appear to be the most significant and robust factors predicting the growth response during crises. Other variables, which are significant in many but not all specifications, are the ratio of short-term debt to reserves, third-country devaluation measure, export growth rate, degree of openness of the economy, and oil price change.

What do our results say about the predictions in the theoretical literature? A positive and significant association between precrisis surge in capital flows and postcrisis contraction is one of the most robust findings of our analysis (confirming the Calvo-Reinhart, 1999, predictions). The coefficient for CAPFLOW varies from -0.35 to -0.26 in different specifications. This implies that if the cumulative external private capital inflows, as a percentage of GDP, in three years prior to the crisis is, say, 10 percent, then this variable alone, assuming all others as constant, is associated with an output contraction of 3.5 percent to 2.6 percent, on average.

However, the coefficient of CAPFLOW*CAPCON is always positive and significant and, in absolute terms, it exceeds the estimated coefficient of CAPFLOW. This result suggests that if the inflow of external capital is associated with a less liberalized capital account regime, then the contraction actually reverses, that is, the economy may experience an expansion in the postcrisis period. In terms of the previous example, it suggests that if a country received external private capital equal to 10 percent or greater of its GDP during the

${ }^{17}$ A useful first step to see the association between the growth variable and the independent variables is to run bi-variate regressions (Table 3). Variables related to capital flows, foreign exchange restrictions, external debt burden, short-term debt and those proxying the initial conditions are closely associated with changes in the growth variable. However, only a few external or policy variables appear significant. To avoid multicollinearity-related problems, we also confirmed that the explanatory variables are not strongly correlated with one another (correlation coefficients range between -0.3 and 0.3 ). 
last three years prior to the crisis, and did so under a relatively closed capital account, then the country is likely to witness an expansion of 3.0 to 3.7 percent during a currency crisis, assuming all other factors as constant. Our analysis does not suggest that closing the capital account during a crisis will prevent output from contracting, but only that if the capital account was already relatively closed before a crisis occurred and if there were large capital inflows in the precrisis years, the economy recovers faster.

The coefficient of the competitive devaluation variable is negative, highly significant and varies little across alternative specifications. This confirms that if trade competitors devalue at the same time that the home country has a currency crisis, output in the latter will contract following the crisis. This result also sheds light on why concurrent crises in several countries are more contractionary than individual ones (Table 2).

The measure of currency overvaluation - the extent by which the real effective exchange rate had appreciated prior to the crisis - is not significant in any of the multivariate regressions. We experimented with several measures of overvaluation-bilateral (with the United States.) as well as multilateral (with trading partners) real exchange rate measures; we also computed changes in this variable over the previous three and five years, but the results remain unchanged. Due to limited availability of data, regressions including this variable were estimated with fewer observations. For brevity, these results are not reported separately in the paper.

The variables related to trade - the export growth rate and the share of trade in economic activity - have a positive and significant impact on growth. The banking crisis dummy has a negative coefficient, though it is mostly insignificant. ${ }^{18}$ While a higher shortterm debt and a larger nominal debt burden are associated with a contraction of economic activity, the significance of the results depends on the sample used (extreme observations or not) and are not robust across specifications.

Regarding domestic control variables, a crisis preceded by a higher output growth rate experiences a bigger contraction during the crisis period (confirming the finding in Milesi-Ferretti and Razin, 1998). Our control for the size/severity of the currency crisis-loss of foreign exchange reserves - has a negative sign in all the specifications, though it is not always significant. Per capita income, on the other hand, has a negative and significant effect on growth across different specifications and samples. This indicates that economies that are at a more advanced stage of development (if per capita income is a good proxy) are more likely to suffer a contraction during a crisis. This is perhaps not surprising if one expects shocks to transmit much faster in more advanced economies where markets function more efficiently and with greater speed.

${ }^{18}$ The banking crisis dummy has a negative sign in all the various specifications, but it is significant, at the 10 percent level, in one regression when all domestic and external variables are included in the specification and the regression includes all the 157 data points. 
Among the global factors, the only variable that is robust to various specifications and has the expected (negative) sign, is the change in oil prices. While the U.S. interest rate has a negative sign, it is not significant in most cases. The terms of trade and the growth rate of G7 countries were also not significant. ${ }^{19}$

Regarding the macroeconomic policy variables, tight monetary policy is associated with a contraction while tight fiscal policies are associated with expansion. While both indicators of monetary policy - money supply and interest rate matter, the only measure of the fiscal stance that is significant is the level of the postcrisis fiscal deficit. The change in the fiscal deficit variable between postcrisis and crisis years turned out to be insignificant, even when it was interacted with the level of the deficit. ${ }^{20}$

The relative contributions of the explanatory variables on the growth variable is shown in Figure 6. Explanatory variables are divided into those that have a negative impact and those that have a positive impact on growth. The figure also indicates the relative importance of the explanatory variables in accounting for the difference between pre- and postcrisis growth rates. While the precrisis cumulative capital flows variable has the strongest negative impact, its interaction with the measure of restriction on the capital flows has the strongest positive impact.

\section{A. Sensitivity Analyses}

We perform a number of sensitivity analyses to test for the robustness of our results. In particular, we test whether different crisis definitions lead to different econometric results and whether the results change over time and across the LEMs and SEMs.

Different studies have used somewhat different criteria to identify crises: BergPattillo and Goldstein-Kaminsky-Reinhart use a composite index of nominal depreciation and reserve loss for a small set of developing countries from Asia and Latin America, while Frankel-Rose and Milesi-Ferretti-Razin use only nominal depreciation to identify crises for 105 low- and middle-income developing countries. We check whether the growth pattern in crisis episodes in the subset of 14 countries that are common across all four studies differ in

${ }^{19}$ In some specifications the estimated coefficients of these variables have counterintuitive signs, though the estimates themselves are not statistically significant.

20 The introduction of the policy variables does marginally change some of our previous results; namely, those related to the nominal debt burden, the short-term debt to reserves ratio, the foreign exchange reserve loss, the export growth, the size of the tradable sector and the oil prices, depending upon which policy variable is included in the regressions. However, given the endogeneity problems inherent in conducting a policy response analysis, these results can only be interpreted as indicating associations. 
any significant way (Table 7). There is some difference in the number and dates of crises each study identifies in these 14 countries. Interestingly, the dates used in our study not only yield a marginally larger average contraction than other studies, but also have a comparable standard deviation.

The distributions of ( $g_{\text {post_2 }}-g_{\text {pre_3,tranq }}$ ) are strikingly similar across different definitions of crises (Figure 4), and a comparable percentage of the crises are found to be expansionary. Also, note that the proportion of expansionary crises in these 14 countries, almost all of which are large emerging markets, is smaller than for the entire sample.

We conduct separate regression analyses for different subsamples based on different definitions of crises. Thus, two samples are created, one on the basis of the definitions provided by the GKR and BP studies, and the other using the FR and MR studies. The results across these two samples are fairly similar (Table 8$).^{21}$

To explore whether the nature of output response changed over time, we reestimated the previous regressions with the decade-specific dummies (Table 9). We conduct this exercise for all 141 crises together, and then separately for the contractionary and expansionary crises. In the three different specifications we confirmed that the average growth response is not significantly different across decades and the coefficients for other variables remain unchanged when these dummies are included. Finally, we also find that the dummies for SEMs and LEMs are not significant in the regressions and that the presence of these dummies does not alter our previous results.

\section{CONCLUding Remarks}

This paper analyzed 195 episodes of currency crises in 91 developing countries during the last three decades and finds that currency crises are associated with diverse output behavior - not only is there diversity in the severity of the contractionary effects of the crises, but a significant proportion of crises in the sample is associated with an expansion. In

${ }^{21}$ The main differences across the two samples are for the following variables: short-term debt to reserves, reserve loss, size of the economy, competitive devaluation and oil prices. In particular, while short-term debt exerts a bigger impact in the GKR/BP sample, it is not significant. Reserve loss does not have a significant impact in the GKR/BP sample; it is significant and negative in the FR/MR sample. A bigger economy implies higher growth during crises in both samples, but the effect is significant and larger only in the GKR/BP sample. An increase in oil prices predicts smaller growth in both samples, but the effect is bigger and significant only in the FR/MR sample. The competitive devaluation variable is negative and significant in the FR/MR and positive but insignificant in the GKR/BP. Regarding the remaining variables, the sign and magnitude of the coefficients and their significance are similar across the two groups. 
addition, the ratio of expansionary to contractionary crises appears not to have changed much across the last three decades; however, the average crisis is more often contractionary in large emerging markets than in small emerging markets. These patterns are independent of the definition used to identify a currency crisis.

The regression results indicate that the higher the volume of private capital flows prior to the crises, the greater the extent of capital account liberalization, the greater the precrisis business cycle boom, and the higher the level of per capita income of the country, then the greater is the contractionary effect of the crises. While the results on trade-related factors are not as strong, growth is higher when the bigger the tradable goods sector and the more exports boom in response to a large devaluation. While global factors together offer a much smaller explanation of growth variation, competitive devaluation by other countries and an increase in crude oil prices are among the relatively more important global factors. Regarding macroeconomic policies, an increase in real interest rate or a tightening of money supply is generally associated with larger contractions, while a tighter fiscal stance is expansionary. 
Table 1. Changes in Growth Rate: Correlation Coefficient Between Different Measures 1/

\begin{tabular}{|c|c|c|c|c|c|c|c|c|c|}
\hline & & A & B & $\mathrm{C}$ & $\mathrm{D}$ & $\mathrm{E}$ & $\mathrm{F}$ & $\mathrm{G}$ & $\mathrm{H}$ \\
\hline $\mathrm{g}_{\text {post_2 }}-\mathrm{g}_{\text {pre } \_2}$ & A & 1.00 & & & & & & & \\
\hline $\mathrm{g}_{\text {post_2 }}-\mathrm{g}_{\text {pre } \_3}$ & B & 0.88 & 1.00 & & & & & & \\
\hline $\mathrm{g}_{\text {post }} 3-\mathrm{g}_{\text {pre_2 }}$ & $\mathrm{C}$ & 0.95 & 0.81 & 1.00 & & & & & \\
\hline $\mathrm{g}_{\text {post_3 }}-\mathrm{g}_{\text {pre_3 }}$ & $\mathrm{D}$ & 0.82 & 0.93 & 0.87 & 1.00 & & & & \\
\hline $\mathrm{g}_{\text {post_2 }}-\mathrm{g}_{\text {pre_2,tranq }}$ & $\mathrm{E}$ & 0.95 & 0.86 & 0.88 & 0.78 & 1.00 & & & \\
\hline g post_2 - g gre_3,tranq & $\mathrm{F}$ & 0.82 & 0.95 & 0.74 & 0.87 & 0.87 & 1.00 & & \\
\hline $\mathrm{g}_{\text {post_3 }}-\mathrm{g}_{\text {pre_2,tranq }}$ & G & 0.91 & 0.89 & 0.86 & 0.79 & 0.84 & 0.91 & 1.00 & \\
\hline $\mathrm{g}_{\text {post_} 3}-\mathrm{g}_{\text {pre } 3 \text {, tranq }}$ & $\mathrm{H}$ & 0.86 & 0.91 & 0.81 & 0.90 & 0.88 & 0.83 & 0.85 & 1.00 \\
\hline
\end{tabular}

Source: Authors' calculations.

$1 /$ Changes in growth rate are measured between the precrisis and postcrises series. 
Table 2. Currency Crises and Output Behavior: Stylized Facts 1/

Dependent Variable: g(post2)-g(pre3, tranq)

Methodology: Least Square

White heteroskedasticity-consistent standard errors \& covariance

\begin{tabular}{|c|c|c|c|c|c|c|}
\hline \multirow[b]{3}{*}{ Variable } & \multirow[b]{3}{*}{ Coefficient } & \multirow[b]{3}{*}{ t-Statistic } & \multicolumn{4}{|c|}{ Wald Coefficient Restriction Tests } \\
\hline & & & & (b1 = b2) & (b1 = b3) & $(b 2=b 3)$ \\
\hline & & & Prob. $1 /$ & Prob. 1/ & Prob. $1 /$ & Prob. 1/ \\
\hline
\end{tabular}

[A] Are there any differences across decades? (All crises, 196 episodes)

\begin{tabular}{|c|c|c|c|c|c|}
\hline $\mathrm{D}(1970 \mathrm{~s})$ & -2.99 & -2.77 & 0.006 & 0.132 & 0.080 \\
\hline$D(1980 s)$ & -1.14 & -1.97 & 0.050 & & \\
\hline $\mathrm{D}(1990 \mathrm{~s})$ & -0.84 & -1.49 & 0.138 & & \\
\hline
\end{tabular}

[B] Are there any differences across decades? (Only contractionary crises, 111 episodes)

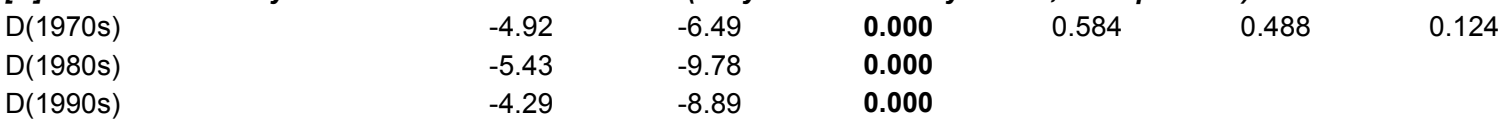

[C] Are there any differences across decades? (Only expansionary crises, 84 episodes)

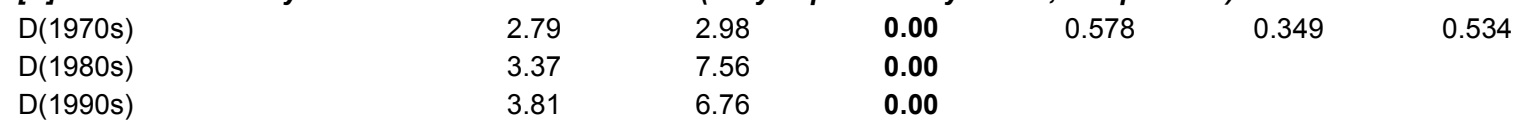

[D] Are there any differences across decades? (Only for crises in Large Emerging Markets)

$\begin{array}{lllllll}D(1970 \mathrm{~s}) & -4.04 & -5.52 & \mathbf{0 . 0 0 0} & 0.349 & 0.258 & 0.879 \\ D(1980 \mathrm{~s}) & -2.96 & -3.35 & \mathbf{0 . 0 0 1} & & & \\ D(1990 \mathrm{~s}) & -2.77 & -3.31 & \mathbf{0 . 0 0 1} & & & \end{array}$

[E] Are concurrent crises more severe?

\begin{tabular}{|c|c|c|c|c|c|}
\hline D (East Asia,1997) & -8.27 & -4.93 & 0.000 & 0.412 & 0.111 \\
\hline D (Latin America Debt, 1980s) & -6.30 & -3.53 & 0.001 & & \\
\hline D (Tequila,1994-95) & -5.06 & -4.14 & 0.000 & & \\
\hline
\end{tabular}

\begin{tabular}{lcccc} 
[F] & Are Crises in Large Emerging Markets & more severe & \multicolumn{4}{c}{ than in Small Emerging Markets? } \\
LEM & -3.07 & -5.94 & $\mathbf{0 . 0 0}$ & $\mathbf{0 . 0 0 0}$ \\
SEM & 0.24 & 0.48 & 0.63 &
\end{tabular}

1/ When "Prob." Is less than 0.1 the LS estimate is significantly different from zero at 10 percent or lower significance level. 
Table 3. Bi-Variate Regressions

Dependent Variable: $g($ post2)-g(pre3, tranq)

Methodology: Least Square

White Heteroskedasticity-Consistent Standard Errors \& Covariance

\begin{tabular}{|c|c|c|c|c|c|c|}
\hline Variable & Coefficient & t-Statistic & Prob. 1/ & R square & $\begin{array}{l}\text { No. of } \\
\text { Crisis } \\
\end{array}$ & $\begin{array}{c}\text { Mean of the } \\
\text { Dep. variable } \\
\end{array}$ \\
\hline \multicolumn{7}{|c|}{ Theoretically Motivate (TM) Variables } \\
\hline CAPFLOW & -0.15 & -3.87 & 0.00 & 0.12 & 173 & -1.364 \\
\hline CAPCON & 2.58 & 1.72 & 0.09 & 0.02 & 188 & -1.133 \\
\hline CAPFLOW*CAPCON & -0.11 & -1.69 & 0.09 & 0.02 & 166 & -1.253 \\
\hline NOMINAL $\triangle \mathrm{DEBT}$ & 0.00 & -17.35 & 0.00 & 0.01 & 178 & -1.003 \\
\hline REAL $\triangle D E B T$ & 0.00 & -5.14 & 0.00 & 0.02 & 161 & -1.178 \\
\hline DEBT_RESERVES & 0.00 & 4.12 & 0.00 & 0.02 & 180 & -1.188 \\
\hline BANK & -0.36 & -0.43 & 0.67 & 0.00 & 182 & -1.064 \\
\hline OVERVAL_MULTI & -1.83 & -3.47 & 0.00 & 0.03 & 124 & -0.683 \\
\hline OVERVAL_US & -2.02 & -2.95 & 0.00 & 0.04 & 161 & -1.160 \\
\hline X_GROWTH & 0.01 & 0.30 & 0.77 & 0.00 & 193 & -1.220 \\
\hline OPEN & -0.01 & -0.72 & 0.47 & 0.00 & 194 & -1.192 \\
\hline COMP_DEVAL & -0.05 & -1.09 & 0.28 & 0.00 & 195 & -1.235 \\
\hline \multicolumn{7}{|c|}{ Domestic Control (DC) Variables } \\
\hline BC_DUM & -3.90 & -9.93 & 0.00 & 0.34 & 195 & -1.235 \\
\hline RESERVE_LOSS & -0.01 & -2.68 & 0.01 & 0.04 & 189 & -1.235 \\
\hline $\mathrm{PCY}$ & -2.08 & -4.84 & 0.00 & 0.11 & 182 & -1.284 \\
\hline GDP & -0.66 & -3.66 & 0.00 & 0.06 & 193 & -1.269 \\
\hline \multicolumn{7}{|c|}{ Global Control (DC) Variables } \\
\hline USINT & -0.22 & -1.78 & 0.08 & 0.02 & 195 & -1.235 \\
\hline GRIND & -0.01 & -0.02 & 0.99 & 0.00 & 195 & -1.235 \\
\hline GRG7 & 0.19 & 0.60 & 0.55 & 0.00 & 195 & -1.235 \\
\hline$\Delta \mathrm{OIL}$ & -0.01 & -1.32 & 0.19 & 0.01 & 195 & -1.235 \\
\hline$\Delta \mathrm{TOT}$ & 0.05 & 1.67 & 0.10 & 0.02 & 193 & -1.269 \\
\hline \multicolumn{7}{|c|}{ Monetary and Fiscal Policy (MFP) Variables and Interaction with Banking Crisis During Crisis } \\
\hline$\Delta \mathrm{M} 2$ & 0.00 & 1.30 & 0.20 & 0.00 & 185 & -1.25 \\
\hline REAL $\Delta$ INT & 0.00 & 1.28 & 0.20 & 0.00 & 147 & -1.15 \\
\hline FISCAL_DEF & 0.03 & 0.39 & 0.70 & 0.00 & 113 & -1.99 \\
\hline$\triangle$ FISCAL_DEF & -0.08 & -0.96 & 0.34 & 0.01 & 106 & -1.85 \\
\hline$\triangle \mathrm{M} 2{ }^{*} \mathrm{BANK}$ & 0.02 & 1.25 & 0.21 & 0.01 & 172 & -1.07 \\
\hline REALAINT*BANK & 0.00 & 1.10 & 0.27 & 0.00 & 135 & -0.95 \\
\hline
\end{tabular}

1/ When "Prob." Is less than 0.1 the LS estimate is significantly different from zero at 10 percent or lower significance level. 
Table 4. Multivariate Regressions

\section{(Theoretically Motivate (TM) and Domestic Control (DC) Variables)}

Dependent Variable: g(post2)-g(pre3, tranq)

Methodology: Least Square

White Heteroskedasticity-Consistent Standard Errors \& Covariance

\begin{tabular}{|c|c|c|c|c|c|c|}
\hline \multirow[b]{2}{*}{ Variable } & \multicolumn{2}{|c|}{ Case -1} & \multicolumn{2}{|c|}{\begin{tabular}{|c|} 
Case - 2 \\
Excluding Hyper Devalua \\
'-tion episodes
\end{tabular}} & \multicolumn{2}{|c|}{$\begin{array}{c}\text { Case - 3 } \\
\text { Excluding Hyper Devalua } \\
\text {-tionary episodes and high } \\
\text { short-term debt to reserves }\end{array}$} \\
\hline & Coefficient & Prob. 1/ & Coefficient & Prob. 1/ & Coefficient & Prob. 1/ \\
\hline \multicolumn{7}{|c|}{ Theoretically Motivate (TM) Variable 3/ } \\
\hline CAPFLOW & -0.32 & 0.000 & -0.32 & 0.000 & -0.31 & 0.000 \\
\hline CAPFLOW*CAPCON & 0.35 & 0.000 & 0.36 & 0.000 & 0.35 & 0.000 \\
\hline NOMINAL $\triangle D E B T$ & 0.00 & 0.000 & 0.00 & 0.122 & 0.00 & 0.289 \\
\hline DEBT_RESERVES 2/ & 0.00 & 0.299 & 0.00 & 0.334 & -0.17 & 0.029 \\
\hline BANK & -0.60 & 0.287 & -0.71 & 0.224 & -0.62 & 0.287 \\
\hline OPEN & 0.03 & 0.005 & 0.02 & 0.013 & 0.02 & 0.055 \\
\hline X_GROWTH & 0.05 & 0.050 & 0.05 & 0.059 & 0.06 & 0.032 \\
\hline \multicolumn{7}{|l|}{ Domestic Control (DC) Variables } \\
\hline BC_DUM & -3.48 & 0.000 & -3.51 & 0.000 & -3.45 & 0.000 \\
\hline RESERVE_LOSS & -0.01 & 0.115 & -0.01 & 0.166 & -0.01 & 0.072 \\
\hline $\mathrm{PCY}$ & -1.15 & 0.005 & -1.06 & 0.010 & -1.37 & 0.001 \\
\hline GDP & 0.23 & 0.296 & 0.27 & 0.213 & 0.21 & 0.348 \\
\hline R squared & & 0.562 & & 0.554 & & 0.572 \\
\hline Adjusted R squared & & 0.526 & & 0.519 & & 0.536 \\
\hline Mean of the Dependent variable & & -1.229 & & -1.210 & & -1.520 \\
\hline Number of Crises & & 157 & & 153 & & 142 \\
\hline
\end{tabular}

1/ When "Prob." Is less than 0.1 the LS estimate is significantly different from zero at 10 percent or lower significance level. 2/ Crises with nominal debt burden exceeding 5000 percent and DEBT_RESERVES exceeding 30 are excluded. 3/ Two of the TM variables_OVERVAL_MULTI, OVERVAL_US, and COMP_DEVAL_are not included in these regressions. Eight separate regressions using different forms of OVERVAL_MULTI, OVERVAL_US measures were estimated,but the variable was not significant in any of these regressions. Results of the regression which include the COMP_DEVAL are reported in Tables 5, 6 and 8. 
Table 5. Multivariate Regressions

(Theoretically Motivate (TM), Domestic Control (DC), and Global Control (GC) Variables)

Dependent Variable: g(post2)-g(pre3, tranq)

Methodology: Least Square

White Heteroskedasticity-Consistent Standard Errors \& Covariance

\begin{tabular}{|c|c|c|c|c|c|c|}
\hline \multirow[b]{2}{*}{ Variable } & \multicolumn{2}{|c|}{ Case -1} & \multicolumn{2}{|c|}{$\begin{array}{c}\text { Case - } 2 \\
\text { Excluding Hyper Devalua- } \\
\text { '-tion episodes }\end{array}$} & \multicolumn{2}{|c|}{\begin{tabular}{|c|} 
Case - 3 \\
Excluding Hyper Devalua \\
-tionary episodes and high \\
short-term debt to reserves
\end{tabular}} \\
\hline & Coefficient & Prob. 1/ & Coefficient & Prob. 1/ & Coefficient & Prob. $1 /$ \\
\hline \multicolumn{7}{|c|}{ Theoretically Motivate (TM) Variables } \\
\hline CAPFLOW & -0.31 & 0.000 & -0.31 & 0.000 & -0.31 & 0.000 \\
\hline CAPFLOW*CAPCON & 0.37 & 0.000 & 0.37 & 0.000 & 0.36 & 0.000 \\
\hline NOMINAL $\Delta$ DEBT & 0.00 & 0.000 & 0.00 & 0.362 & 0.00 & 0.451 \\
\hline DEBT_RESERVES & 0.00 & 0.890 & 0.00 & 0.994 & -0.14 & 0.078 \\
\hline BANK & -0.95 & 0.090 & -0.94 & 0.106 & -0.79 & 0.189 \\
\hline OPEN & 0.02 & 0.012 & 0.02 & 0.023 & 0.02 & 0.066 \\
\hline X_GROWTH & 0.05 & 0.052 & 0.05 & 0.061 & 0.06 & 0.035 \\
\hline COMP_DEVAL & -0.08 & 0.038 & -0.08 & 0.055 & -0.07 & 0.076 \\
\hline \multicolumn{7}{|l|}{ Domestic Control (DC) Variables } \\
\hline BC_DUM & -3.54 & 0.000 & -3.54 & 0.000 & -3.50 & 0.000 \\
\hline RESERVE_LOSS & 0.00 & 0.191 & 0.00 & 0.253 & -0.01 & 0.126 \\
\hline PCY & -1.22 & 0.005 & -1.13 & 0.010 & -1.34 & 0.003 \\
\hline GDP & 0.26 & 0.230 & 0.28 & 0.199 & 0.23 & 0.324 \\
\hline \multicolumn{7}{|l|}{ Global Control (DC) Variables } \\
\hline USINT & -0.17 & 0.067 & -0.14 & 0.159 & -0.08 & 0.433 \\
\hline$\Delta \mathrm{OIL}$ & -0.02 & 0.064 & -0.02 & 0.071 & -0.02 & 0.076 \\
\hline$\Delta \mathrm{TOT}$ & 0.02 & 0.338 & 0.02 & 0.414 & 0.02 & 0.538 \\
\hline GRG7 & -0.16 & 0.542 & -0.07 & 0.772 & -0.02 & 0.951 \\
\hline R squared & & 0.589 & & 0.583 & & 0.592 \\
\hline Adjusted R squared & & 0.542 & & 0.534 & & 0.540 \\
\hline Mean of the Dependent variable & & -1.229 & & -1.210 & & -1.520 \\
\hline Number of Crises 2/ & & 157 & & 153 & & 142 \\
\hline
\end{tabular}

1/ When "Prob." Is less than 0.1 the LS estimate is significantly different from zero at 10 percent or lower significance level.

2/ Crises with nominal debt burden exceeding 5000 percent and DEBT_RESERVES exceeding 30 are excluded. 
Table 6. Multivariate Regressions
(Theoretically Motivate (TM), Domestic Control (DC), Global Control (GC), and Monetary and Fiscal Policy (MFP) Variables)

Dependent Variable: $\mathrm{g}($ post2)-g(pre3, tranq)

Methodology: Least Square

White Heteroskedasticity-Consistent Standard Errors \& Covariance

\begin{tabular}{|c|c|c|c|c|c|c|}
\hline \multirow[b]{2}{*}{ Variable } & \multicolumn{2}{|c|}{$\begin{array}{c}\text { A } \\
\text { Monetary Policy (Instru- } \\
\text {-ment: Money Supply }\end{array}$} & \multicolumn{2}{|c|}{$\begin{array}{c}\text { B } \\
\text { Monetary Policy (Instru- } \\
\text {-ment: Interest rate }\end{array}$} & \multicolumn{2}{|c|}{\begin{tabular}{|c|} 
C \\
Fiscal Policy (Instrument \\
Budget Deficit
\end{tabular}} \\
\hline & Coefficient & Prob. 1/ & Coefficient & Prob. 1/ & Coefficient & Prob. $1 /$ \\
\hline \multicolumn{7}{|c|}{ Theoretically Motivate (TM) Variables } \\
\hline CAPFLOW & -0.35 & 0.000 & -0.26 & 0.000 & -0.30 & 0.002 \\
\hline CAPFLOW*CAPCON & 0.38 & 0.000 & 0.31 & 0.001 & 0.37 & 0.011 \\
\hline NOMINAL $\triangle \mathrm{DEBT}$ & 0.00 & 0.705 & -0.02 & 0.053 & 0.00 & 0.375 \\
\hline DEBT_RESERVES & -0.14 & 0.070 & -0.17 & 0.035 & -0.17 & 0.110 \\
\hline BANK & -0.70 & 0.232 & -0.72 & 0.293 & -0.85 & 0.313 \\
\hline OPEN & 0.02 & 0.025 & 0.01 & 0.301 & 0.00 & 0.864 \\
\hline X_GROWTH & 0.04 & 0.107 & 0.06 & 0.060 & 0.06 & 0.079 \\
\hline COMP_DEVAL & -0.07 & 0.079 & -0.09 & 0.061 & -0.11 & 0.069 \\
\hline \multicolumn{7}{|l|}{ Domestic Control (DC) Variables } \\
\hline BC_DUM & -3.41 & 0.000 & -3.79 & 0.000 & -3.97 & 0.000 \\
\hline RESEERVE_LOSS & -0.01 & 0.009 & -0.01 & 0.084 & 0.00 & 0.400 \\
\hline $\mathrm{PCY}--$ & -1.43 & 0.001 & -1.00 & 0.037 & -1.97 & 0.002 \\
\hline GDP & 0.32 & 0.167 & -0.02 & 0.927 & 0.41 & 0.142 \\
\hline \multicolumn{7}{|l|}{ Global Control (DC) Variables } \\
\hline USINT & -0.09 & 0.391 & -0.08 & 0.505 & -0.17 & 0.162 \\
\hline$\Delta \mathrm{OIL}$ & -0.02 & 0.067 & 0.00 & 0.908 & -0.02 & 0.011 \\
\hline$\Delta \mathrm{TOT}$ & 0.01 & 0.772 & -0.01 & 0.643 & 0.01 & 0.743 \\
\hline GRG7 & -0.03 & 0.907 & 0.00 & 0.991 & -0.16 & 0.624 \\
\hline \multicolumn{7}{|c|}{ Monetary and Fiscal Policy (MFP) Variables } \\
\hline$\Delta \mathrm{M} 2$ & 0.01 & 0.000 & - & - & - & - \\
\hline REALAINT & - & - & -0.02 & 0.037 & - & - \\
\hline FISCAL_DEF & - & - & - & - & 0.19 & 0.037 \\
\hline R squared & & 0.621 & & 0.642 & & 0.600 \\
\hline Adjusted R squared & & 0.569 & & 0.574 & & 0.507 \\
\hline Mean of the Dependent variable & & -1.539 & & -1.400 & & -1.915 \\
\hline Number of Crises 2/ & & 141 & & 107 & & 96 \\
\hline
\end{tabular}

1/ When "Prob." Is less than 0.1 the LS estimate is significantly different from zero at 10 percent or lower significance level.

2/ Crises with nominal debt burden exceeding 5000 percent and DEBT_RESERVES exceeding 30 are excluded. 
Table 7. Descriptive Statistics of (gpost_2 - gpre_3, tranq) Under Alternative Crisis-Identifying Criteria $1 /$

\begin{tabular}{|c|c|c|c|c|c|c|}
\hline $\begin{array}{l}\text { Studies Using Alternative Crisis- } \\
\text { Identifying Criteria }\end{array}$ & Mean & Median & Max. & Min. & $\begin{array}{l}\text { Std. } \\
\text { Dev. }\end{array}$ & $\begin{array}{l}\text { \# of } \\
\text { Crises }\end{array}$ \\
\hline $\begin{array}{l}\text { Goldstein, Kaminsky, and } \\
\text { Reinhart (2000) }\end{array}$ & -2.6 & -2.7 & 10.6 & -14.5 & 5.6 & 58 \\
\hline Berg and Patillo (1999) & -3.0 & -3.4 & 8.1 & -14.5 & 5.0 & 46 \\
\hline Frankel and Rose (1996) & -2.5 & -1.8 & 12.2 & -16.6 & 5.7 & 53 \\
\hline Milesi-Ferretti and Razin (1998) & -4.4 & -4.6 & 8.4 & -16.6 & 5.9 & 30 \\
\hline $\begin{array}{l}\text { Based on dates used in this paper } \\
\text { (See Appendix B) }\end{array}$ & -3.8 & -4.1 & 6.4 & -14.5 & 4.9 & 46 \\
\hline
\end{tabular}

1/ For the 14 countries common across all four studies. 
Table 8. Sensitivity Analysis

(Subsamples Based on Alternative Currency Crisis-Identifying Criteria)

Dependent Variable: g(post2)-g(pre3, tranq)

Methodology: Least Square

White Heteroskedasticity-Consistent Standard Errors \& Covariance

\begin{tabular}{|c|c|c|c|c|}
\hline Variable & \multicolumn{2}{|c|}{$\begin{array}{c}\text { Case }-1 \\
\text { Only Those Crises Identified by GKR or BP } 2 /\end{array}$} & \multicolumn{2}{|c|}{$\begin{array}{c}\text { Case - } 2 \\
\text { Only Those Crises Identified } \\
\text { by FR or MR } 2 /\end{array}$} \\
\hline Theoretically Motivate (TM) Vari & & & & \\
\hline $\begin{array}{l}\text { CAPFLOW } \\
\text { CAPFLOW*CAPCON } \\
\text { NOMINAL_DEBT } \\
\text { DEBT_RESERVES } \\
\text { BANK } \\
\text { OPEN } \\
\text { X_GROWTH } \\
\text { COMP_DEVAL }\end{array}$ & \begin{tabular}{r|}
-0.34 \\
0.43 \\
0.00 \\
-0.24 \\
-1.26 \\
0.02 \\
0.03 \\
0.09
\end{tabular} & $\begin{array}{l}\mathbf{0 . 0 1 5} \\
\mathbf{0 . 0 0 4} \\
0.288 \\
0.351 \\
0.299 \\
\mathbf{0 . 4 0 0} \\
0.602 \\
0.433\end{array}$ & $\begin{array}{r}-0.39 \\
0.43 \\
0.00 \\
-0.15 \\
-0.87 \\
0.01 \\
0.03 \\
-0.08\end{array}$ & $\begin{array}{l}\mathbf{0 . 0 0 0} \\
\mathbf{0 . 0 0 0} \\
0.762 \\
\mathbf{0 . 0 5 9} \\
0.183 \\
0.154 \\
0.187 \\
\mathbf{0 . 0 6 3}\end{array}$ \\
\hline $\begin{array}{l}\text { Domestic Control (DC) Variable } \\
\text { BC_DUM } \\
\text { RESERVE_LOSS } \\
\text { PCY } \\
\text { GDP }\end{array}$ & $\begin{array}{c}-3.57 \\
0.00 \\
-2.32 \\
1.28\end{array}$ & $\begin{array}{l}\mathbf{0 . 0 0 2} \\
0.792 \\
\mathbf{0 . 0 3 8} \\
\mathbf{0 . 0 1 5}\end{array}$ & $\begin{array}{r}-3.39 \\
-0.01 \\
-1.44 \\
0.22\end{array}$ & $\begin{array}{l}\mathbf{0 . 0 0 0} \\
\mathbf{0 . 0 0 9} \\
\mathbf{0 . 0 0 2} \\
0.373\end{array}$ \\
\hline $\begin{array}{l}\text { Global Control (DC) Variables } \\
\text { USINT } \\
\Delta \text { OIL } \\
\Delta \text { TOT } \\
\text { GRG7 }\end{array}$ & $\begin{array}{r}-0.09 \\
-0.01 \\
0.02 \\
0.37\end{array}$ & $\begin{array}{l}0.695 \\
0.403 \\
0.640 \\
0.434\end{array}$ & $\begin{array}{l}-0.03 \\
-0.02 \\
0.00 \\
-0.10\end{array}$ & $\begin{array}{l}0.763 \\
\mathbf{0 . 0 7 8} \\
0.861 \\
0.693\end{array}$ \\
\hline $\begin{array}{l}\text { Monetary Policy Variable } \\
\Delta \mathrm{M} 2\end{array}$ & 0.02 & 0.016 & 0.01 & 0.000 \\
\hline $\begin{array}{l}\text { R squared } \\
\text { Adjusted } R \text { squared } \\
\text { Mean of the Dependent variable } \\
\text { Number of Crises }{ }^{* *}\end{array}$ & & $\begin{array}{c}0.671 \\
0.464 \\
-4.828 \\
45\end{array}$ & & $\begin{array}{c}0.642 \\
0.574 \\
-1.400 \\
107\end{array}$ \\
\hline
\end{tabular}

1/ When "Prob." Is less than 0.1 the LS estimate is significantly different from zero at 10 percent or lower significance level. $2 /$ Crises with nominal debt burden exceeding 5000 percent and DEBT_RESERVES exceeding 30 are excluded. 
Table 9. Sensitivity Analysis

(Based on the Stylized Facts Identified in Section III)

Dependent Variable: $\mathrm{g}$ (post2)-g(pre3, tranq)

Methodology: Least Square

White Heteroskedasticity-Consistent Standard Errors \& Covariance

\begin{tabular}{lllllll}
\hline \multicolumn{7}{c}{$\begin{array}{c}\text { All explanatory variables used in Table 6, Case } 1 \text { are included in the regressions, except the } \\
\text { constant term is replaced by a number of exhaustive dummies. }\end{array}$} \\
\hline Variable & Coefficient & t-Statistic & Prob. 1 & R square & $\begin{array}{c}\text { No. of } \\
\text { Crisis }\end{array}$ & $\begin{array}{c}\text { Mean of the } \\
\text { Dep. variable }\end{array}$ \\
\hline
\end{tabular}

Is there any Decadal variation? (All Crises)

$\begin{array}{lllllll}\mathrm{D}(1970 \mathrm{~s}) & 5.07 & 1.11 & 0.27 & 0.562 & 141 & -1.539 \\ \mathrm{D}(1980 \mathrm{~s}) & 5.26 & 1.10 & 0.27 & & & \\ \mathrm{D}(1990 \mathrm{~s}) & 4.91 & 1.04 & 0.30 & & & \end{array}$

\begin{tabular}{|c|c|c|c|c|c|c|}
\hline \multicolumn{7}{|c|}{ Is there any Decadal variation? (Only Contractionary Crises) } \\
\hline $\mathrm{D}(1970 \mathrm{~s})$ & 1.36 & 0.27 & 0.78 & 0.305 & 84 & -4.92 \\
\hline $\mathrm{D}(1980 \mathrm{~s})$ & -1.13 & -0.23 & 0.82 & & & \\
\hline $\mathrm{D}(1990 \mathrm{~s})$ & -0.16 & -0.03 & 0.97 & & & \\
\hline
\end{tabular}

Is there any Decadal variation? (Only Expansionary Crises)
$D(1970 \mathrm{~s})$
$D(1980 \mathrm{~s})$

\begin{tabular}{|c|c|c|c|c|c|c|}
\hline $\mathrm{D}(1970 \mathrm{~s})$ & 5.67 & 0.48 & 0.64 & 0.555 & 70 & -3.186 \\
\hline $\mathrm{D}(1980 \mathrm{~s})$ & 6.30 & 0.50 & 0.62 & & & \\
\hline $\mathrm{D}(1990 \mathrm{~s})$ & 5.17 & 0.41 & 0.69 & & & \\
\hline
\end{tabular}

Is there any Decadal variation? (Only for Crises in Small Emerging Markets)

$\begin{array}{lllllll}\mathrm{D}(1970 \mathrm{~s}) & -2.55 & -0.20 & 0.84 & 0.452 & 71 & 0.085 \\ \mathrm{D}(1980 \mathrm{~s}) & -3.03 & -0.23 & 0.82 & & & \\ \mathrm{D}(1990 \mathrm{~s}) & -2.45 & -0.18 & 0.85 & & & \end{array}$

Do Contagious Crises Continue to be more Severe?

$\begin{array}{lllllll}\text { D (East Asia,1997) } & 2.62 & 0.43 & 0.67 & 0.567 & 141 & -1.539 \\ \text { D (Latin America Debt, 1980s) } & 2.56 & 0.49 & 0.63 & & & \\ \text { D (Tequila,1994-95) } & 7.43 & 1.29 & 0.20 & & \\ \text { D (Rest All Crises) } & 4.04 & 0.83 & 0.41 & & \end{array}$

Do Crises in Large Emerging Markets Continue to be More Severe than in Small Emerging Markets?

$\begin{array}{lllllll}\text { LEM } & 2.62 & 0.43 & 0.67 & 0.567 & 141 & -1.539 \\ \text { SEM } & 2.56 & 0.49 & 0.63 & & & \end{array}$

1/ When "Prob." Is less than 0.1 the LS estimate is significantly different from zero at 10 percent or lower significance level. 
Figure 1. Magnitude of Contraction/Expansion During Selected Currency Crises

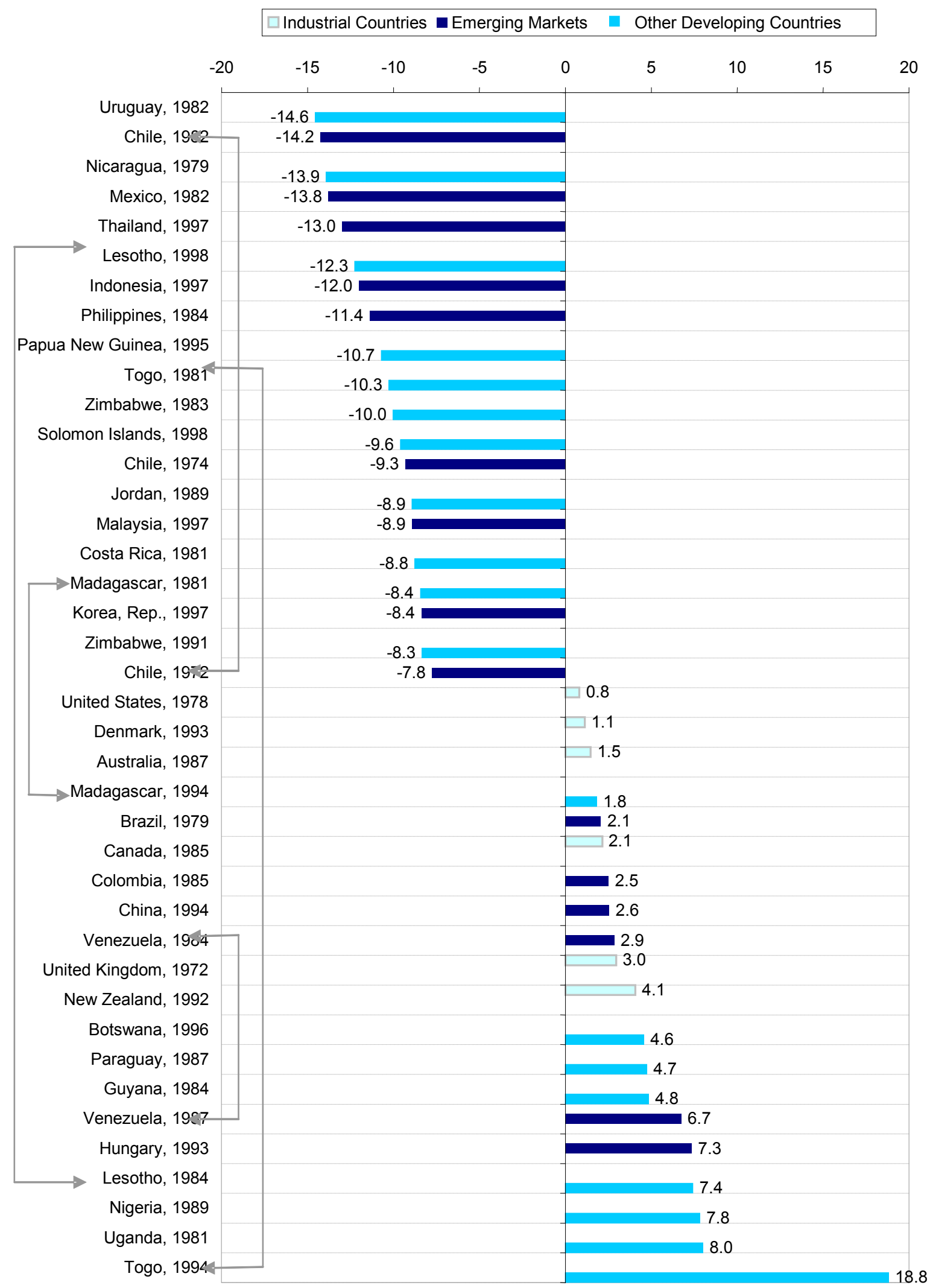


Figure 2. Frequency Distribution of Average Growth Rate During the Crisis and One PostCrisis Year

Average growth rate in crisis year T and the next year T+1, g_post2

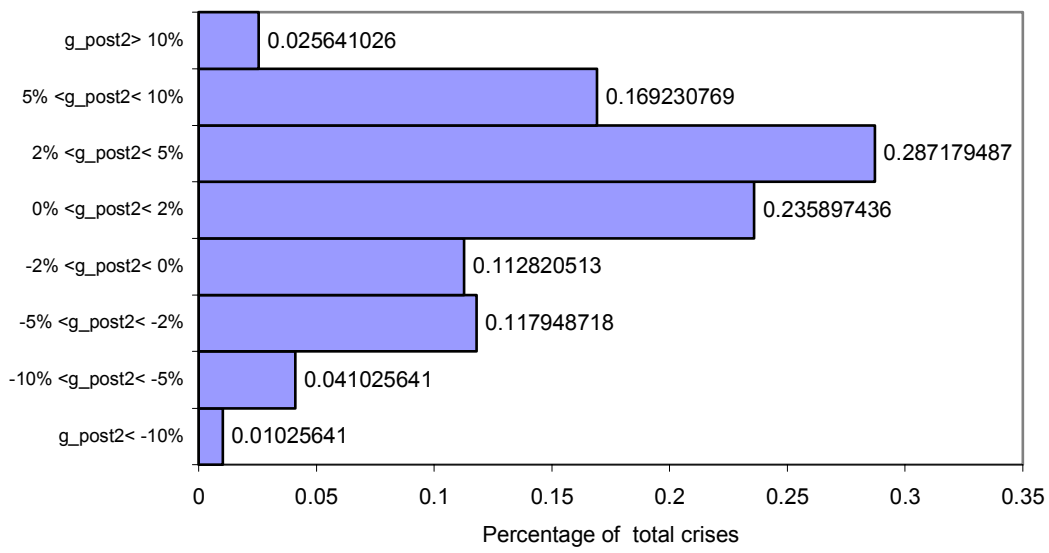

\begin{tabular}{|lr|}
\hline \multicolumn{2}{|c|}{ Descriptive } \\
statistics of g_post2 \\
Mean & 1.65 \\
Median & 1.80 \\
Maximum & 12.30 \\
Minimum & -11.14 \\
Std. Dev. & 4.04 \\
Skewness & -0.29 \\
Kurtosis & 3.56 \\
Jarque-Bera & 5.26 \\
Probability & 0.07 \\
\# of Crises & 195 \\
\# of Countries & 108 \\
\hline
\end{tabular}

Figure 3: Frequency Distribution of [g(post_2) - g(pre_3,tranq) $]^{*}$

Average growth rate in $T$ and $T+1$, g_post2, minus average growth rate in 3 tranquil periods, g_pre3 (tranq)

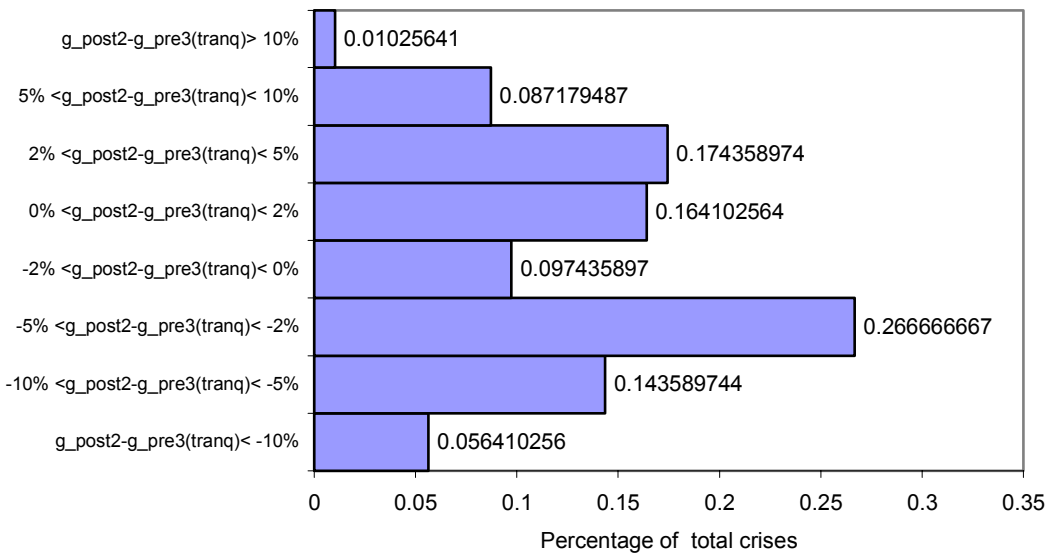

\begin{tabular}{|lr|}
\hline \multicolumn{2}{|c|}{ Descriptive } \\
statistics of \\
g_post2-g_pre3(tranq) \\
Mean & -1.20 \\
Median & -0.47 \\
Maximum & 18.82 \\
Minimum & -14.55 \\
Std. Dev. & 5.30 \\
Skewness & 0.01 \\
Kurtosis & 3.56 \\
Jarque-Bera & 2.51 \\
Probability & 0.28 \\
\# of Crises & 195 \\
\# of Countries & 108 \\
\hline
\end{tabular}

Note: Magnitude of Contraction / Expansion = g_post2 - g_pre3 (tranq), where g_post2 is the average growth rate in T and T+1, where $\mathrm{T}$ is the crisis year. g_pre3 (tranq) is the average growth rate in T-1, T-2, and T-3 years.

If there is a crisis between T-1 and T-3, the nearest 3 consecutive tranquil (non-crisis) periods are used instead. 
Figure 4. Frequency Distribution of [g(post_2) - g(pre_3, tranq)] Under Alternative CrisisIdentifying Criteria for the 14 Countries Common Across Four Studies

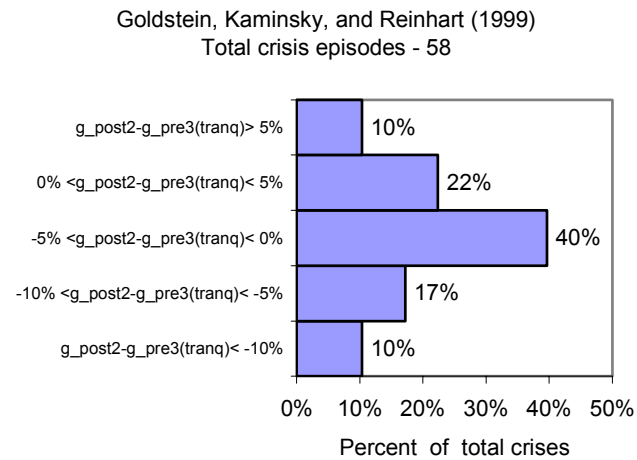

Frankel and Rose (1996)

Total crisis episodes - 53

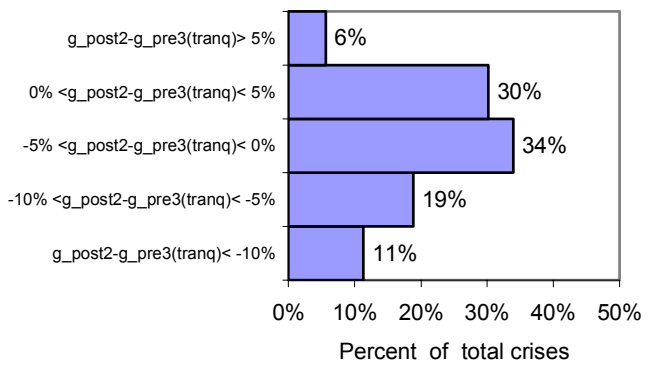

Berg and Patillo (2000)

Total crisis episodes - 46

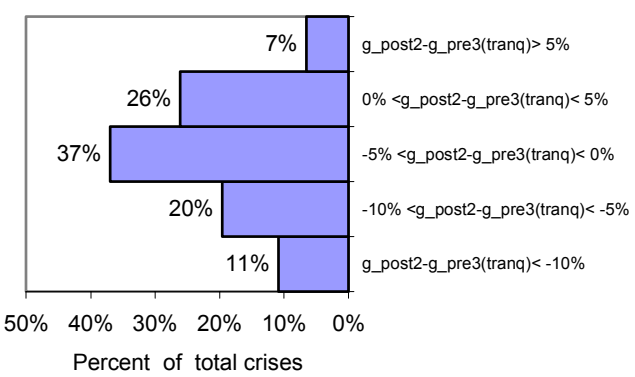

Milesi-Ferretti and Razin (1999)

Total crisis episodes -30

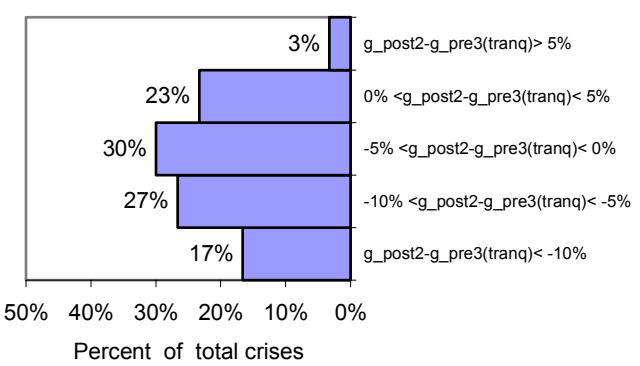

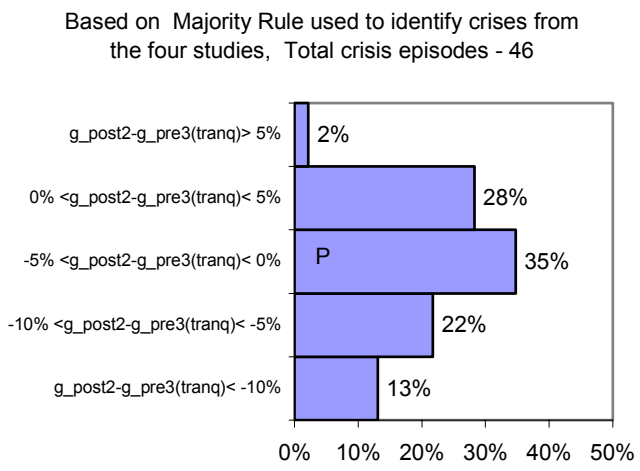

Percent of total crises

Note: Magnitude of Contraction / Expansion $=g \_$post2 $-g \_p r e 3$ (tranq), where g_post2 is the average growth rate in $T$ and $T+1, T$ is the crisis year. g_pre3 (tranq) is the average growth rate in T-1, T-2, and T-3 years. If there is a crisis between T-1 and T-3, the nearest 3 consecutive tranquil (noncrisis) periods are used instead. The above estimates are based on the following fourteen countries: Argentina, Bolivia, Brazil, Chile, Colombia, Indonesia, Korea, Mexico, Peru, Philippines, Thailand, Turkey, Uruguay, and Venezuela. 
Figure 5. Severity of Crises : A Comparison Across Three Decades

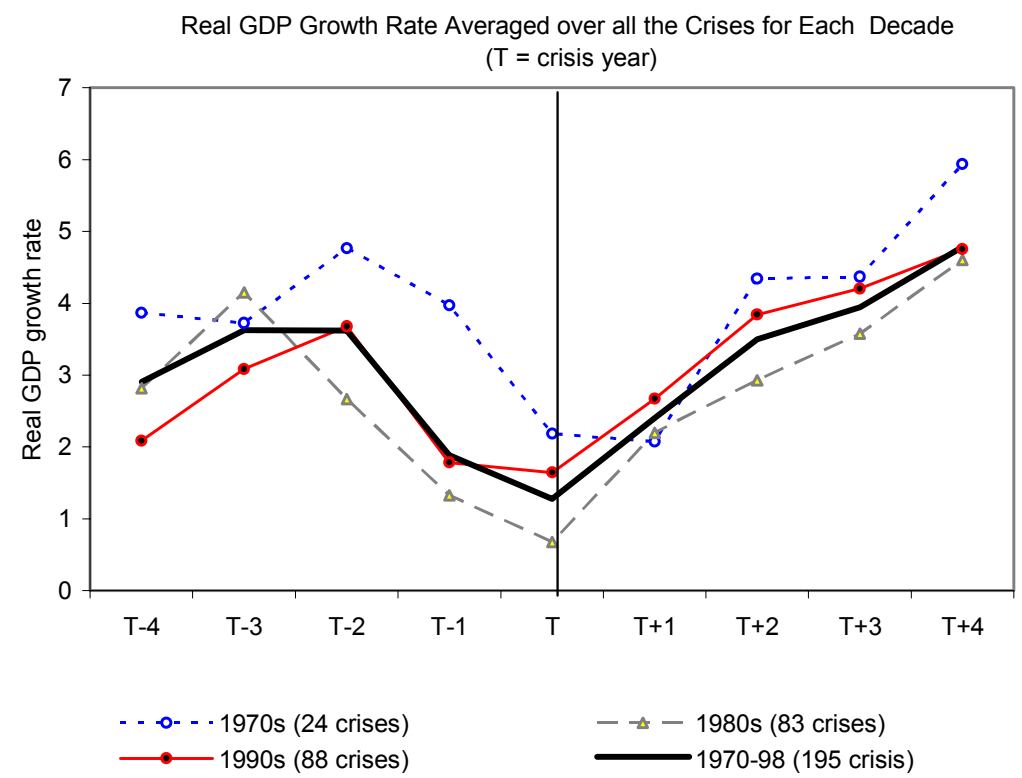

Frequency Distribution of the Extent of Contraction/Expansion in Growth Rate During Crisis, for Each Decade

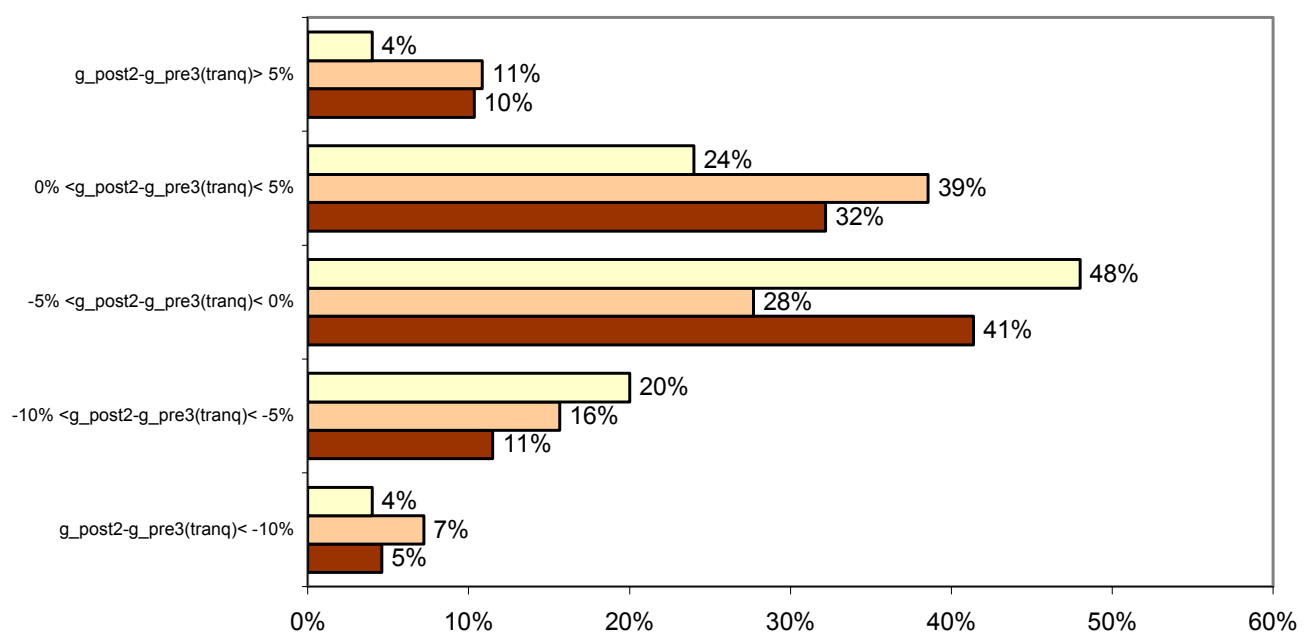

$\square$ 1990s (88 crisis episodes) $\square$ 1980s (84 crisis episodes) $\square$ 1970s (24 crises)

Note: Magnitude of Contraction / Expansion = g_post2 - g_pre3 (tranq), where g_post2 is the average growth rate in $T$ and $T+1$, where $T$ is the crisis year. g_pre3 (tranq) is the average growth rate in $T-1, T-2$, and $T-3$ years. If there is a crisis between T-1 and T-3, the nearest 3 consecutive tranquil (noncrisis) periods are used instead. 


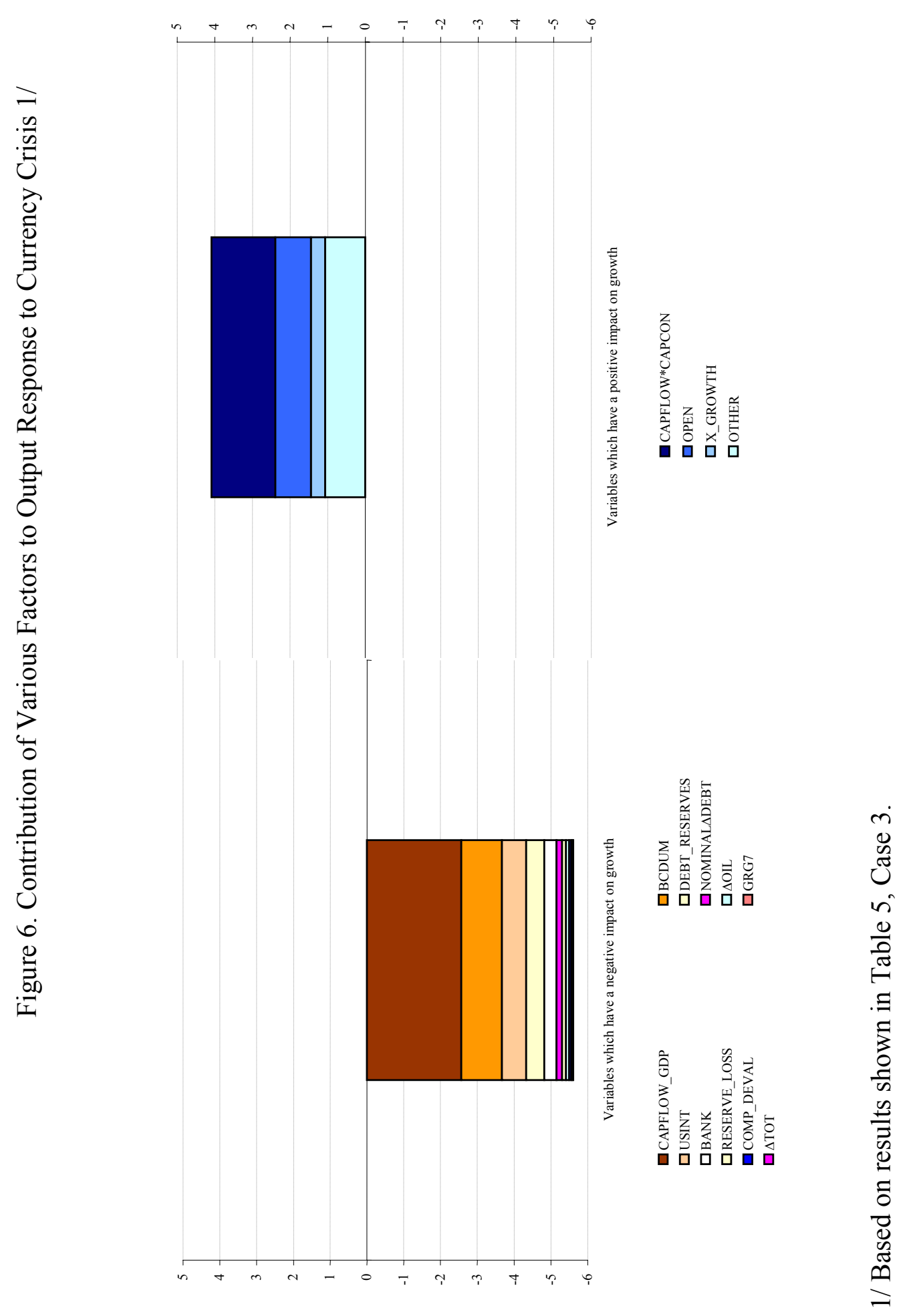




\section{Countries in the Sample}

Africa (47 countries): Algeria, Benin, Botswana, Burkina Faso, Burundi, Cameroon, Cape Verde, Central African Republic, Chad, Comoros, Congo, Dem. Rep. of, Congo, Rep. of, Cote d'Ivoire, Djibouti, Equatorial Guinea, Ethiopia, Gabon, The Gambia, Ghana, Guinea, Guinea-Bissau, Kenya, Lesotho, Liberia, Madagascar, Malawi, Mali, Mauritania, Mauritius, Morocco, Niger, Nigeria, Rwanda, Sao Tome and Principe, Senegal, Seychelles, Sierra Leone, Somalia, South Africa, Sudan, Swaziland, Tanzania, Togo, Tunisia, Uganda, Zambia, Zimbabwe.

Asia (excluding Middle East, 21 countries): Bangladesh, Bhutan, China, Fiji, India, Indonesia, Korea, Rep. , Lao PDR, Malaysia, Maldives, Myanmar, Nepal, Pakistan, Papua New Guinea, Philippines, Samoa, Solomon Islands, Sri Lanka, Taiwan Province of China, Thailand, Vanuatu.

Latin America (26 countries): Argentina, Barbados, Belize, Bolivia, Brazil, Chile, Colombia, Costa Rica, Dominican Republic, Ecuador, El Salvador, Grenada, Guatemala, Guyana, Haiti, Honduras, Jamaica, Mexico, Nicaragua, Panama, Paraguay, Peru, St. Vincent and the Grenadines, Trinidad and Tobago, Uruguay, Venezuela.

Other Countries (14 countries): Czech Republic, Egypt, Hungary, Islamic Republic of Iran, Israel, Jordan, Lebanon, Malta, Oman, Romania, Syrian Arab Republic, Turkey, Yemen, Yugoslavia.

\section{Large Emerging Markets}

Algeria, Argentina, Bolivia, Brazil, Chile, China, Colombia, Costa Rica, Czech Republic, Dominican Republic, Ecuador, Egypt, Hungary, India, Indonesia, Jordan, Korea, Rep., Malaysia, Mexico, Morocco, Nigeria, Pakistan, Panama, Papua New Guinea, Peru, Philippines, Romania, South Africa, Thailand, Trinidad and Tobago, Tunisia, Turkey, Uruguay, Venezuela.

\section{Small Emerging Markets}

Bangladesh, Barbados, Belize, Benin, Bhutan, Botswana, Burkina Faso, Burundi, Cameroon, Cape Verde, Central African Republic, Chad, Comoros, Congo, Dem. Rep. of, Congo, Cote d'Ivoire, Djibouti, El Salvador, Equatorial Guinea, Ethiopia, Fiji, Gabon, The Gambia, Ghana, Grenada, Guatamala, Guinea, Guinea-Bissau, Guyana, Haiti, Honduras, Islamic Republic of Iran, Israel, Jamaica, Kenya, Lebanon, Lesotho, Liberia, Madagascar, Malawi, Maldives, Mali, Malta, Mauritania, Mauritius, Myanmar, Nepal, Nicaragua, Niger, Oman, Paraguay, Rwanda, Samoa, Sao Tome and Principe, Senegal, Seychelles, Sierra Leone, Solomon Islands, Somalia, Sri Lanka, St. Vincent and the Grenadines, Serbia and Montenegro (formerly Yugoslavia), Sudan, Swaziland, Syrian Arab Republic, Taiwan Province of China, Tanzania, Togo, Uganda, Vanuatu, Yemen, Zambia, Zimbabwe. 


\section{The Crisis Episodes}

The crisis episodes used in the paper are defined in five different ways: two definitions used by Milesi-Ferretti-Razin (1998) and one each by Frankel-Rose (1996), Berg-Pattillo (1999), and Goldstein-Kaminsky-Reinhart (2000). ${ }^{22}$

Milesi-Ferretti and Razin (MR): (i) A crisis occurs when the nominal depreciation of the currency is at least 25 percent, which is at least double the previous year's depreciation, and the latter is below 40 percent. (ii) A crisis occurs when the nominal depreciation of the currency is at least 15 percent, at least 10 percent higher than the previous year's depreciation, with the latter below 10 percent. Their sample includes 105 low and middle income countries, and the time period covered is 1970-96.

Frankel and Rose (FR): A crisis occurs when the nominal depreciation of the currency is at least 25 percent, which is at least 10 percent higher than previous year. The sample includes 105 developing countries, and the time period covered is 1971-1992.

Berg and Pattillo (BP): A crisis occurs when the index of speculative pressure (weighted average of exchange rate and foreign exchange reserve changes, with weights assigned such that the conditional volatilities of the components are equal) is at least two standard deviation higher than the mean. The sample includes 23 emerging market economies, and the time period covered is 1970-97.

Goldstein, Kaminsky and Reinhart (GKR): A crisis occurs when the index of speculative pressure (weighted average of exchange rate and foreign exchange reserve changes, with weights assigned such that the conditional volatilities of the components are equal) is at least two standard deviation higher than the mean. The sample includes 25 countries, 1970-1998.

${ }^{22}$ Some of these studies exclude crisis dates that are "too close" to each other. As a starting point, we include all dates, but our majority rule automatically excludes crises too close to each other. 


\section{Data Sources and Construction of Variables}

\begin{tabular}{|c|c|c|c|c|}
\hline Variable & Definition & Unit & Data $1 /$ & Sources 2/ \\
\hline $\mathrm{g}_{\text {post_2 }}-\mathrm{g}_{\text {pre_3,tranq }}$ & $\begin{array}{l}\text { Difference between the average real GDP growth rates in } \mathrm{T} \\
\text { and } \mathrm{T}+1 \text { and three precrisis tranquil years. }\end{array}$ & $\begin{array}{l}\text { Percentage } \\
\text { points }\end{array}$ & $\begin{array}{c}\mathrm{T}-3, \ldots \\
\mathrm{T}+1\end{array}$ & $\begin{array}{l}\text { GDF, WDI Central, } \\
\text { or WEO. }\end{array}$ \\
\hline CAPFLOW & Three year cumulative capital flows as a share of GDP & Ratio & $\mathrm{T}-3, ., \mathrm{T}-1$ & GDF, WDI Central \\
\hline CAPCON & $\begin{array}{l}\text { Precrisis restrictions on foreign exchange and capital } \\
\text { account transactions, constructed by taking an average of } \\
\text { the dummies for restrictions on capital account or exchange } \\
\text { rate regime during the three years prior to the crisis. }\end{array}$ & $\begin{array}{l}0 \text { to } 1, \\
\text { where } \\
0 \text { implies } \\
\text { no controls. }\end{array}$ & $\begin{array}{l}\mathrm{T}-3, \ldots . . \\
\mathrm{T}-1\end{array}$ & $\begin{array}{l}\text { Constructed using } \\
\text { the data from } \\
\text { Milesi-Ferretti and } \\
\text { Razin (1998). }\end{array}$ \\
\hline $\begin{array}{l}\text { NOMINAL } \Delta \text { DEBT } \\
\text { AND REAL } \Delta \text { DEBT }\end{array}$ & $\begin{array}{l}\text { Change in long-term debt burden, measured as the annual } \\
\text { percentage change in external long-term debt. The nominal } \\
\text { change in debt is measured in dollars, while the real change } \\
\text { in debt is defleted by the prevailing exchange rate. }\end{array}$ & Percent & $\mathrm{T}$ and $\mathrm{T}-1$ & $\begin{array}{l}\text { Nominal debt: GDF } \\
\text { and WDI Central; } \\
\text { Exchange rate: IFS }\end{array}$ \\
\hline DEBT_RESERVES & $\begin{array}{l}\text { Precrisis ratio of short-term external debt to international } \\
\text { reserves }\end{array}$ & Ratio & $\mathrm{T}-1$ & $\begin{array}{l}\text { GDF, WDI Central; } \\
\text { Reserves: IFS }\end{array}$ \\
\hline BANK & $\begin{array}{l}\text { Banking crisis dummy. Used three existing studies and } \\
\text { majority rule to select the banking crises dates. A twin } \\
\text { crisis is defined when a banking crisis occurs within a year } \\
\text { of a currency crisis. }\end{array}$ & $\begin{array}{l}0 \text { if no twin } \\
\text { crisis, } 1 \text { if } \\
\text { twin crisis }\end{array}$ & $\mathrm{T}$ & $\begin{array}{l}\text { Caprio et al. (1995), } \\
\text { Lindgren et al. } \\
\text { (1997), Goldstein } \\
\text { et al. (1999). }\end{array}$ \\
\hline X_GROWTH & Export growth during the crisis and one post crisis year. & Percent & $\mathrm{T}$ and $\mathrm{T}+1$ & GDF, WDI Central \\
\hline OPEN & $\begin{array}{l}\text { Size of the tradable sector, that is, exports plus imports as a } \\
\text { share of GDP }\end{array}$ & Ratio & $\mathrm{T}-1$ & $\begin{array}{l}\text { GDF and WDI } \\
\text { Central }\end{array}$ \\
\hline COMP_DEVAL & Competitive Devaluation Effect. 3/ & $\begin{array}{l}\text { Percentage } \\
\text { change }\end{array}$ & $\mathrm{T}$ and $\mathrm{T}-1$ & JP Morgan \\
\hline PCY & Purchasing power adjusted GDP per capita in year t-1. & in US \$ & $\mathrm{T}-1$ & GDF, WDI Central \\
\hline GDP\$ & Size of the economy in terms of US dollars & in US \$ & $\mathrm{T}-1$ & WEO \\
\hline BCDUM & $\begin{array}{l}\text { dummy that takes a value of }-1 \text { if the three year precrisis } \\
\text { average growth rate is less than } 0 \text { percent, } 0 \text { if the growth } \\
\text { rate is between } 0 \text { and } 3 \text { percent, and }+1 \text { if the growth rate } \\
\text { exceeded } 3 \text { percent. }\end{array}$ & $\begin{array}{l}\text { Index takes } \\
\text { a value }-1 \\
\quad 0 \text { or } 1 .\end{array}$ & $\begin{array}{c}\mathrm{T}-3, \ldots . \\
\mathrm{T}-1\end{array}$ & $\begin{array}{l}\text { GDF, WDI Central } \\
\text { where available, } \\
\text { otherwise WEO. }\end{array}$ \\
\hline RESERVE_LOSS & Change in international reserves between $\mathrm{T}-1$ and $\mathrm{T}$ & Percent & $\mathrm{T}$ and $\mathrm{T}-1$ & $\begin{array}{l}\text { Foreign Exchange } \\
\text { Reserves: IFS }\end{array}$ \\
\hline USINT & The US Federal Fund Rate & Percent & $\mathrm{T}$ & IFS \\
\hline GRG7 & $\begin{array}{l}\text { Weighted average of real growth rate of the G7 countries, } \\
\text { weights= respective GDP }\end{array}$ & Percent & $\mathrm{T}$ and $\mathrm{T}-1$ & GDF, WDI Central \\
\hline GRIND & Growth rate in industrial countries & Percent & $\mathrm{T}$ and $\mathrm{T}-1$ & GDF, WDI Central \\
\hline$\Delta \mathrm{OIL}$ & $\begin{array}{l}\text { Change in crude oil price in the crisis year over the } \\
\text { previous year. }\end{array}$ & Percent & $\mathrm{T}$ and $\mathrm{T}-1$ & IFS \\
\hline$\Delta \mathrm{TOT}$ & Change in terms of trade during T over T-1. & Percent & $\mathrm{T}$ and $\mathrm{T}-1$ & GDF, WDI Central \\
\hline OVERVAL & Change in the REER/ RER between T-1 and T- 3 or T- 5 & Percent & $\begin{array}{l}\mathrm{T}-1, \mathrm{~T}- \\
3, \mathrm{~T}-5 \\
\end{array}$ & \\
\hline$\Delta \mathrm{M} 2$ & $\begin{array}{l}\text { Change in the real growth rate of broad money supply } \\
\text { during crisis year over the previous year. }\end{array}$ & Percent & $\mathrm{T}$ and $\mathrm{T}-1$ & IFS \\
\hline REALAINT & Change in the real interest rate over the previous year. & $\begin{array}{l}\text { Percentage } \\
\text { points }\end{array}$ & $\mathrm{T}-1$ and $\mathrm{T}$ & IFS \\
\hline FISCAL_DEF & Fiscal deficit as a share of GDP. & Ratio & $\mathrm{T}+1$ & \\
\hline$\triangle$ FISCAL_DEF & Change in Fiscal DEFICIT & $\begin{array}{l}\text { Percentage } \\
\text { points }\end{array}$ & $\mathrm{T}$ and $\mathrm{T}+1$ & GDF, WDI Central \\
\hline
\end{tabular}

$1 / \mathrm{T}$ refers to the crisis year. In cases where there was a crisis between T-3 and T-1 years, the growth rates during the previous tranquil periods are used.

2/ World Bank, Global Development Finance (GDF); etc.

3/ Using the data on REER for 21 LEM from JP Morgan, we constructed REER (competitor) ${ }_{j}=\frac{\sum_{i \neq j} \text { REER }}{20}$. The percentage change in REER (competitor) is used as a measure of the average real devaluation in competitor countries. For the rest 70 countries, the REER (competitor) variable is based on all 21 observations. 


\section{References}

Agenor, Pierre-Richard, 1991, "Output, Devaluation and the Real Exchange Rate in Developing Countries," Weltwirtschaftliches Archiv, Vol. 127, pp. 18-41.

Aziz, Jahangir, Francesco Caramazza, and Ranil Salgado, 2000, "Currency Crises: In Search of Common Elements," IMF Working Paper 00/67 (Washington: International Monetary Fund).

Berg, Andrew and Catherine Patillo, 1999, "Are Currency Crises Predicable? A Test," IMF Staff Papers, Vol. 46, pp. 107-38.

Bordo, Michael, Barry Eichengreen, Daniela Klingebiel, 2001, "Is the Crisis Problem Growing More Severe?” Economic Policy, Vol. 32, pp. 51-82.

Bruno, Michael, 1979, "Stabilization and Stagflation in a Semi-Industrialized Economy," in International Economics Policy: Theory and Evidence, ed. by Rudiger Dornbusch and Jacob A. Frenkel, pp. 270-89.

Calvo, Guillermo, A., 1998, "Capital Flows and Capital Market Crises: The Simple Economics of Sudden Stops," Journal of Applied Economics, Vol. 1 (November), pp. 35-54.

Calvo, Guillermo, A., and Carmen M. Reinhart, 1999, "When Capital Inflows Come to a Sudden Stop: Consequences and Policy Options" (unpublished; Maryland: University of Maryland).

Caprio, Gerald. J., and Daniela Klingebiel, 1996, "Bank Insolvencies: Cross Country Experience," World Bank Policy Research Working Paper No. 1620 (Washington: World Bank).

Connolly, Michael, 1983, "Exchange Rates, Real Economic Activity and the Balance of Payments: Evidence from the 1960s," in Recent Issues in the Theory of the Flexible Exchange Rates, ed. by E. Classen and P. Salin (Amsterdam: North-Holland).

Edwards, Sebastian, 1986, “Are Devaluations Contractionary?," The Review of Economics and Statistics, Vol. 68, pp. 501-7.

Economist Intelligence Unit, 2001, Country Report, (London: EUI).

Frankel, Jeffery and Andrew Rose, 1996, "Currency Crashes in Emerging Markets: An Empirical Treatment,” Journal of International Economics, Vol. 41, pp. 351-66.

Goldstein Morris, Graciela L. Kaminsky, and Carmen M. Reinhart, 2000, Assessing Financial Vulnerability: An Early Warning System for Emerging Markets (Washington: Institute for International Economics). 
International Monetary Fund, 1998, World Economic Outlook, 1998, A Survey by the Staff of the International Monetary Fund, World Economic and Financial Surveys, (Washington).

Kamin, Steven B, and Marc Klau, 1998, "Some Multi-Country Evidence on the Effects of Real Exchange Rates on Output," International Finance Discussion Paper No. 611 (Washington: Board of Governors of the Federal Reserve System).

Kaminsky, Graciela L. and Carmen M. Reinhart, 1999, "The Twin Crises: The Causes of Banking and Balance of Payments Problems," American Economic Review, Vol. 89 (June), pp. 473-500.

Kraay, Aart, 1999, "In Search of Macroeconomic Effects of Capital Account Liberalization," (Washington: World Bank).

Lahiri, Amartya and Carlos Végh, 1999, “Output Costs, BOP Crises and Optimal Interest Rate Policy," (unpublished; Los Angeles: University of California).

Lindgren, Carl-Johan, Gillian Garcia, and Matthew I. Saal, 1996, Bank Soundness and Macroeconomic Policy (Washington: International Monetary Fund).

Lizondo, Saul J. and Peter J. Montiel, 1989, "Contractionary Devaluation in Developing Countries," IMF Staff Papers, Vol. 36 (March) pp. 182-227.

Milesi-Ferretti, Gian Maria and Assaf Razin, 1998, "Current Account Reversals and Currency Crises: Empirical Regularities,” IMF Working Paper 98/89 (Washington: International Monetary Fund).

Mishkin, Frederic S., 1999, "Global Financial Instability: Framework, Events, Issues," Journal of Economic Perspective, Vol. 13, No. 4, pp. 3-20.

Morley, Samuel A., 1992, "On the Effect of Devaluation During Stabilization Programs in LDCs," Review of Economics and Statistics.

Rodrik, Dani, 1998, “Who Needs Capital Account Convertibility?” available via the Internet at http://ksghome.harvard.edu/ .drodrik.academic.ksg/essay.pdf

Rodrik, Dani and Andres Velasco, 1999, "Short-Term Capital Flows," NBER Working Paper, W7364 (Cambridge, Mass.: National Bureau of Economic Research).

Stiglitz, Joseph, 1999, “Must Financial Crises Be This Frequent and This Painful?” in The Asian Financial Crises: Causes, Contagion and Consequences, ed. by P. R. Agenor, M. Miller, and D. Vines (Cambridge: Cambridge University Press).

Taylor, Lance, and Jeffrey Rosensweig, 1990, Devaluation, Capital Flows and Crowding Out: A CGE Model with Portfolio Choice for Thailand (Cambridge, Mass.: MIT Press). 


$$
\text { - } 36 \text { - }
$$

Van Wijnbergen, Sweder, 1986, "Exchange Rate Management and Stabilization Policies in Developing Countries," Journal of Development Economics (Amsterdam), Vol. 23, pp. 227-47. 